\title{
Olga Krasnoukhova*
}

\section{Attributive modification in South American indigenous languages}

\author{
https://doi.org/10.1515/ling-2020-0133
}

Received June 29, 2020; accepted September 9, 2021; published online February 14, 2022

\begin{abstract}
The article deals with attributive modification in South American languages. It focuses on descriptive terms that denote properties. First of all, it is observed that attributive modification with property terms is possible in most, but not all South American languages. The typology of attributive constructions is argued to constitute a continuum, from syntactically loose nominal expressions, on the one hand, to morphologically complex structures which are ambiguous between compounding and derivation, on the other hand. The latter involves the use of lexico-grammatical means such as classifiers. The paper also raises the question of a possible diachronic link - at least for some languages - between intransitive clauses and postnominal property terms, which are often verbal in nature.
\end{abstract}

Keywords: attributive modification; noun phrase; predication; property concepts; South American languages

\section{Introduction}

This study deals with the way attributive modification is expressed in South American ('SA') indigenous languages. It is concerned with a functional equivalent of attributively used property concepts, such as 'big tree', 'old dog', or 'white clouds'. By a 'property concept' I refer to a descriptive element that denotes a property or quality, narrowing down the interpretation of the referent noun. Semantically, it encompasses the types in (1), which are identified in Dixon (1977, 1982, 2004a: 5, 2010: 74) as prototypical.

\footnotetext{
*Corresponding author: Olga Krasnoukhova, Centre for Linguistics, Leiden University, Reuvensplaats 3-4, 2311 BE Leiden, The Netherlands; and University of Antwerp, Antwerpen, Belgium, E-mail: o.krasnoukhova@hum.leidenuniv.nl. https://orcid.org/0000-0002-1953-7954 
(1) Semantic types under investigation:

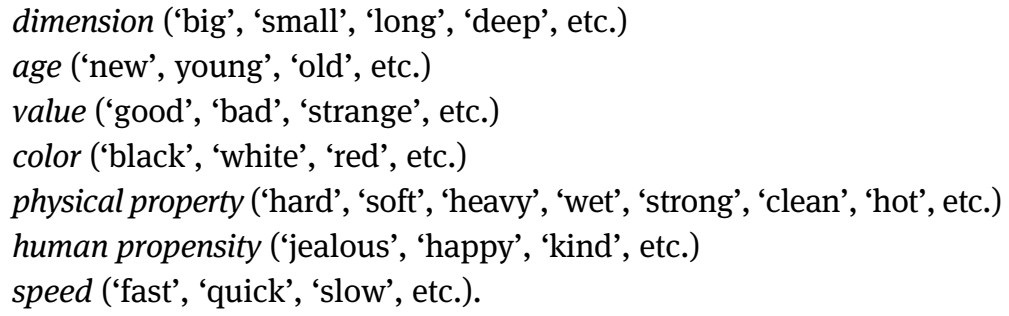

The topic of attributive modification in SA languages has received a preliminary treatment in Krasnoukhova (2012: Ch. 6), who identified a number of tendencies. This study differs in a number of ways. First, it takes a more fine-grained approach by examining each semantic type. Second, it offers a typology of attributive modification in the languages of this continent. It was shown by Foley's (1980: 174) study of Austronesian languages that different types of modifiers in a noun phrase (NP) typically differ in the strength of the syntactic bond with their head noun, running from strong to weak along a 'Bondedness Hierarchy'. This study argues that a similar range of syntactic bondedness is also relevant within one modifier type.

It should be noted that SA languages have started to be explored from a typological perspective only relatively recently. They are still underrepresented in typological studies treating morpho-syntax of attributive modification. For example, Rijkhoff's (2002: 5-10) study on the NP structure includes only four SA languages. ${ }^{1}$ A study by Rießler (2016), although devoted to an exploration of attributive modification by property concepts in the languages of Northern Eurasia, does include observations for a world-wide sample of 71 languages, among which three SA indigenous languages. ${ }^{2}$ The present study aims to contribute to a

1 This may be a consequence of following Ruhlen's (1991[1987]) classification of the world's languages. Ruhlen groups all SA languages under one 'Amerind' family divided into six subphyla, including languages spoken in North America. That view on genealogical classification of SA languages is radically different from the current view, for example, in Hammarström et al. (2020). The SA languages included in Rijkhoff's (2002: 6) sample are Hixkaryana, Guaraní, Ika and Imbabura Quechua.

2 It should be noted that the scope of inquiry in the present study is somewhat different from the one in Rießler (2016). The latter explicitly focuses on grammatical devices "used for the encoding of the syntactic relationship between an adjectival dependent and its head noun" (Rießler 2016: 8). First, different from this study, Rießler (2016) is not concerned with non-integral NPs. Second, while Rießler (2016) takes a fine-grained approach to different subtypes of integral NPs, this study is more concerned with a broader division of attributive construction along the line of syntactic bondedness. Note that Rießler (2016: 254-255) mentions that his world-wide sample is "unbalanced". Nevertheless, I will refer to Rießler's results whenever relevant and possible. The SA 
fuller picture of attributive modification with data that have received little attention so far.

This study is based on a sample of 65 SA languages. These represent 41 families, 12 of which constitute unclassified or isolate languages. For larger families languages from different internal branches are selected. The availability of a better and detailed grammatical description has played an additional role in the choice for a representative. The sample is as balanced as possible from an areal perspective. Note, however, that the Northern part of South America has a considerably higher language density as compared to the Southern part of the continent, ${ }^{3}$ and the Southern languages are also less well described (see Campbell and Grondona 2012: 628-630). This is inevitably reflected in the current sample, where the North is better represented than the South. Appendix 1 shows the geographic distribution of the languages. The full list of sample languages and their genealogical affiliation can be found in Table 1.

The paper is organized as follows. Section 2 introduces the issue of property concepts crosslinguistically and offers an inventory of word classes with which property concepts are associated in the sample languages. The overview is followed by observations on the data. Section 3 focuses on the attributive use of property concepts. I propose a typology of constructions used for attributive modification, ranging in syntactic complexity and bondedness with their head nouns. Sections 3.1-3.7 zoom in on each type illustrated by a selection of languages. Section 4 offers some diachronic considerations. Section 5 is the conclusion.

\section{How properties are expressed in SA languages}

There is ample crosslinguistic evidence that property concepts can be encoded by lexemes from different word classes. Thus, in language A, a concept such as 'big' is encoded by a verb, showing little or no difference in morphological and syntactic behavior from a verb like 'sit'. In language B, a lexeme denoting 'big' has properties of a noun. In language $\mathrm{C}$, 'big' behaves like a prototypical adverb. In language D, 'big' is among the lexemes that are 'flexible' (Hengeveld 1992), covering not only properties but also entities and events. Finally, in language E, a lexeme meaning 'big' has morphological and syntactic properties of its own, different from those of

languages included in Rießler's (2016: 245-252, 254-255) world-wide sample are Hixkaryana, Mapudungun and Wari'; I do not count in Berbice Dutch Creole.

3 More specifically, the Southern Cone, which is the geographic area below the Tropic of Capricorn. 


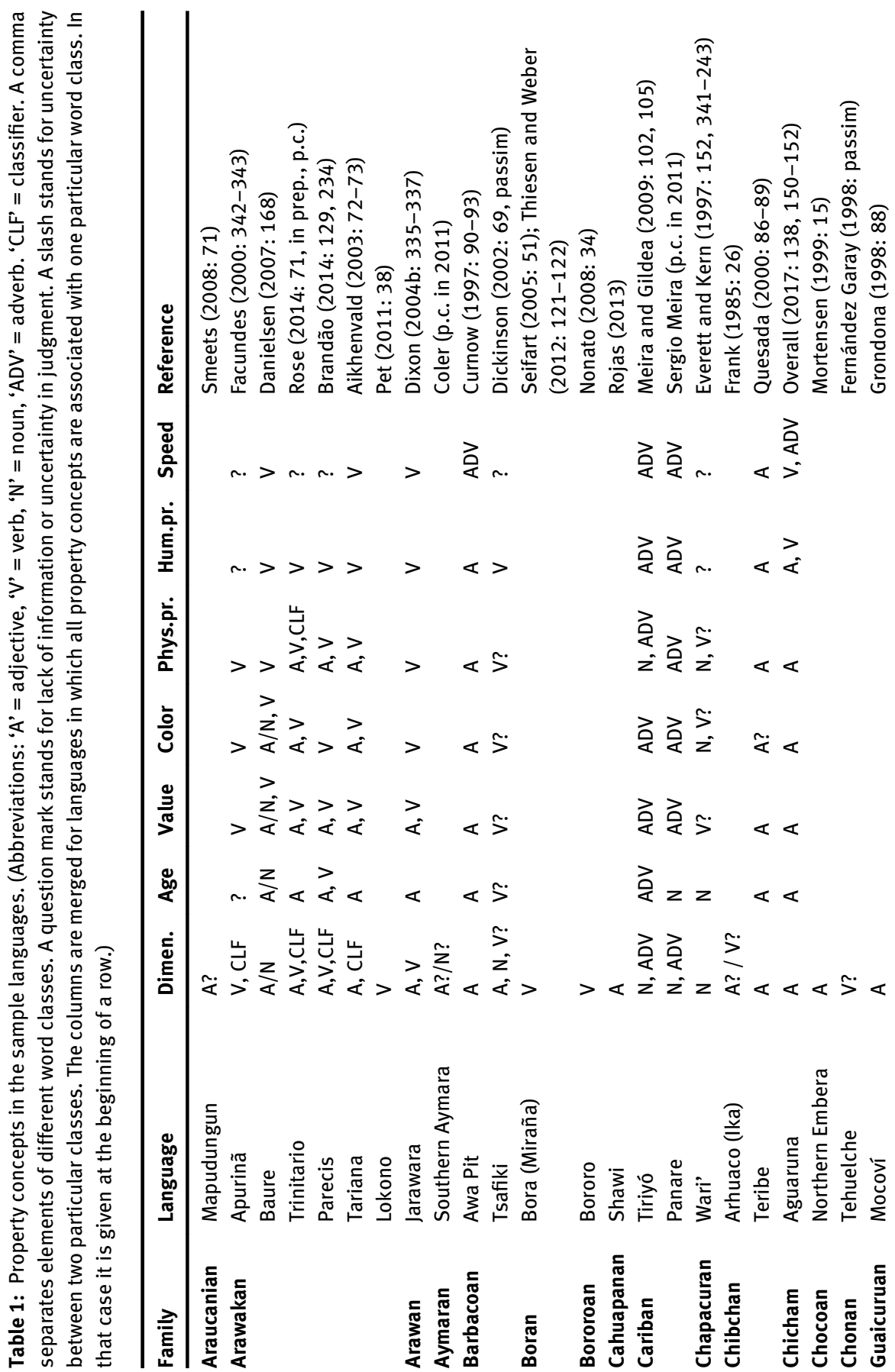




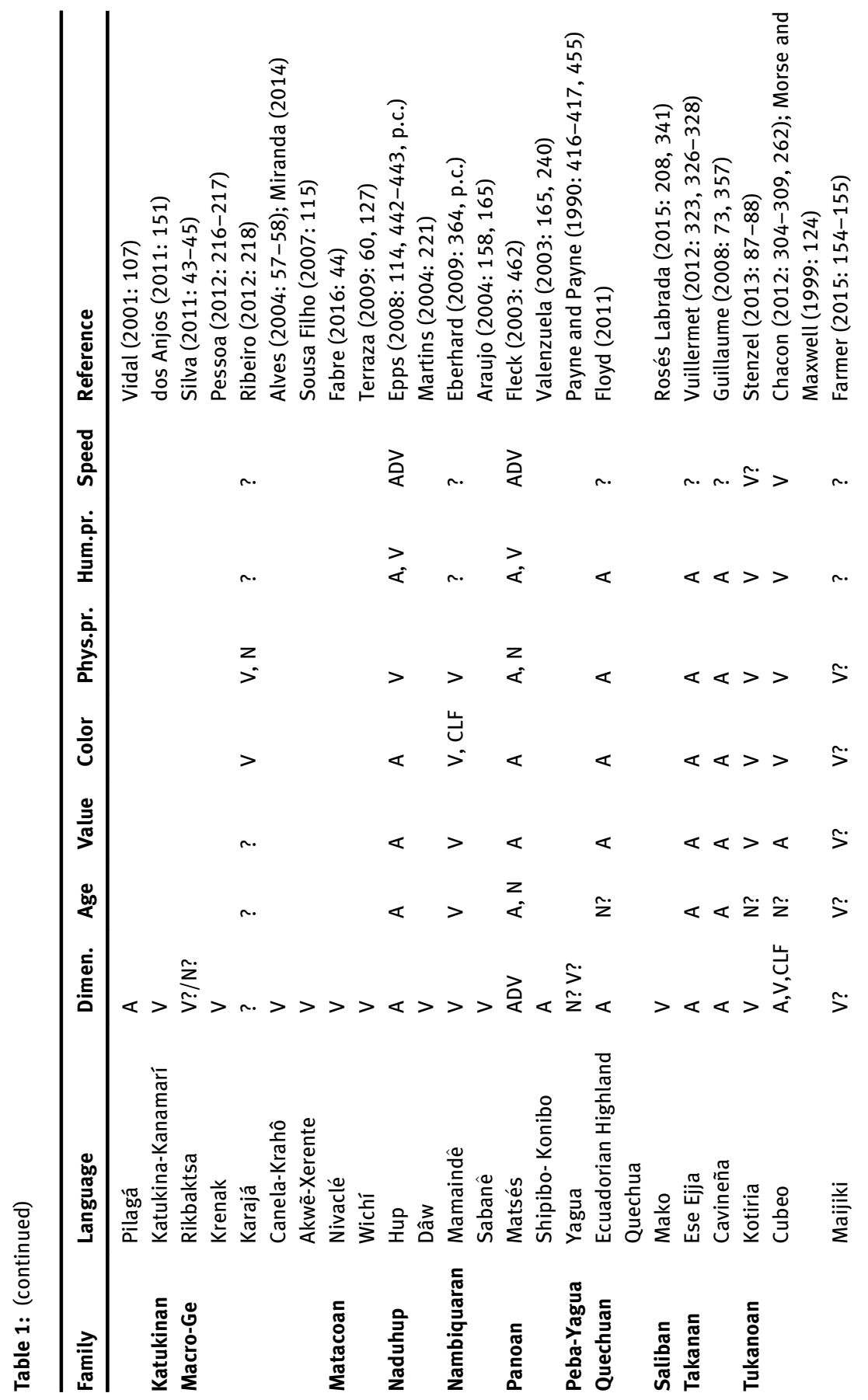




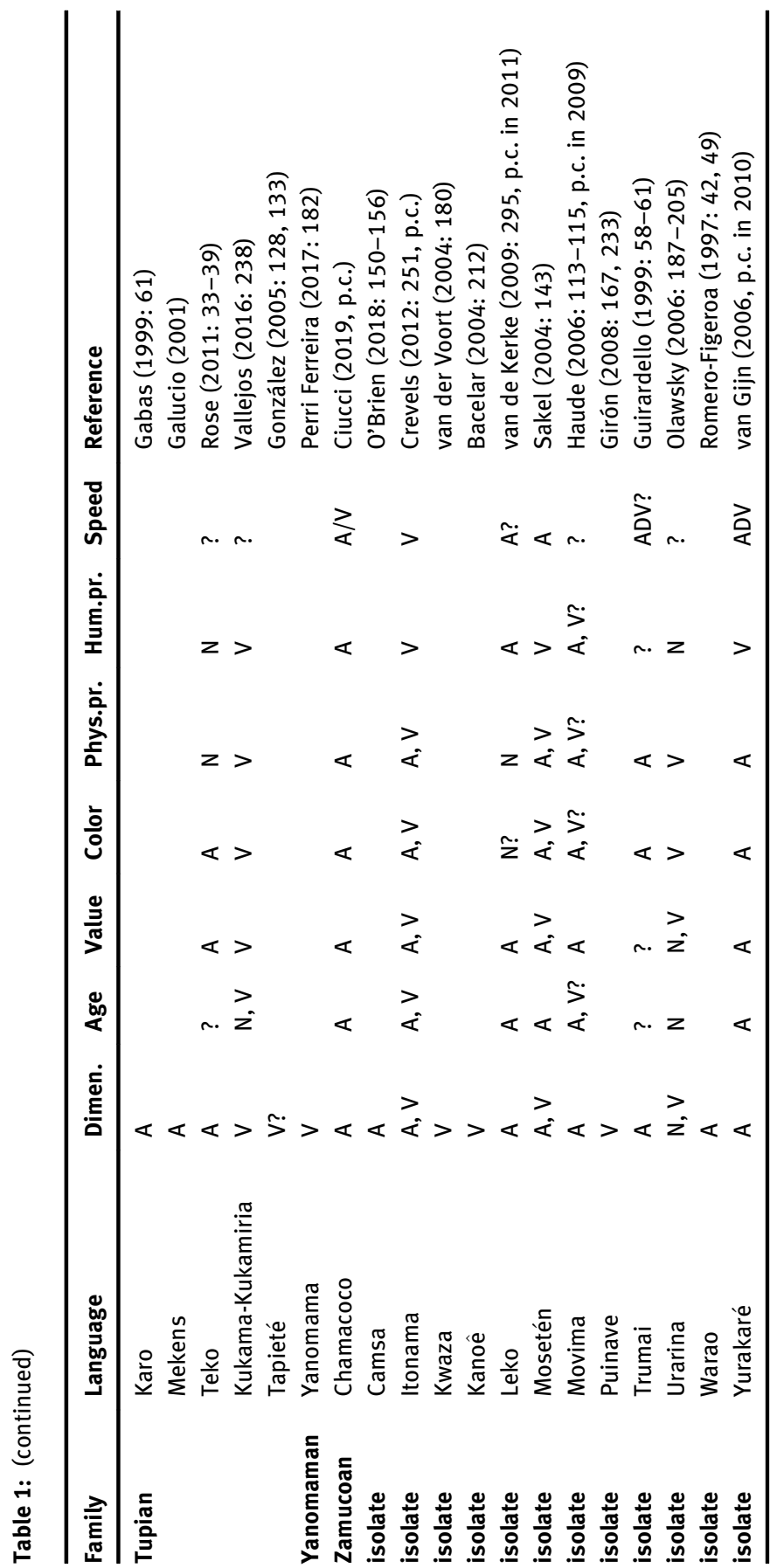


nouns, verbs, or adverbs. SA languages reflect this crosslinguistic picture: we find all these cases in the sample.

The morphosyntactic status of a lexeme denoting a property determines the way it is realized in attributive modification. For example, if a property concept is associated with the class of verbs, whose prototypical function is predication, the attributively used property concept will typically carry extra morphology (Beck 2002: 83-84; Croft 1991, 2003: 185; Haspelmath 2012: 125). This can be illustrated by Kukama-Kukamiria (2): property concepts are verbal roots that take a nominalizer when used as modifiers.

\section{Kukama-Kukamiria (Tupian) \\ emete awa yurutsima epewatsu-n \\ exist people lips be.thick-nMLZ}

'There are people with thick lips.' (Lit. 'Thick-lip people exist')

(Vallejos 2016: 242)

In this light it is useful to address the question of how the semantic types in (1) are expressed in the languages under investigation. An attempt to plot a word class for each semantic type is given in Table $1 .{ }^{4}$ It must be noted that the judgments on a word class are heavily based on analyses as found in corresponding language descriptions. For some languages, all property concepts are argued to be associated with one particular word class; for such languages the columns are merged. Finally, as it is shown in the paper, some languages use not only lexical means for the function of attributive modification, but also classifiers, viz. elements with a semi-grammatical status. These are identified in Table 1 as 'CLF'. It should also be mentioned that the analysis of property concepts as belonging to a certain word class is based on their synchronic status, not on a diachronic one. ${ }^{5}$

4 I call it an "attempt" for a number of reasons. First, judgments on a word class, with which a property concept is associated, are mainly based on analyses given in language descriptions. The sources differ with respect to the depth and breadth with which this topic is addressed. In some cases, the available information is scarce. Whenever possible, I use my own judgment based on an existing description and examples. Second, as with any topic, a more focused investigation on property concepts in a language will likely bring in the necessary adjustments. Despite these obvious shortcomings, I suggest that the available data are sufficient to draw a number of conclusions of general relevance.

5 To give an example: in Movima, most color terms are monomorphemic and share many characteristics with nouns. The term for 'black' tun-ni is morphologically complex, and unless it combines with a bound nominal root, it always contains the verbalizing suffix -ni. However, despite its similarities with verbs, it diverges from them synchronically. Haude (2006: 113-118) suggests that this term belongs to the adjective class together with the other color terms and some other property concepts. 
The data in Table 1 allow us to make a number of general observations:

- First of all, a substantial portion of the sample languages, i.e., at least 29 languages out of 65 , do not have a separate adjective class. The use of verbs to encode properties is a more common strategy than the use of nouns or adverbs in that case. In 21 languages (32\% of the sample) properties are encoded mainly (or only) by verbs.

- Second, in many sample languages terms that denote properties are heterogeneous across the semantic types, i.e., property concepts are encoded by roots belonging to different word classes. It was already observed by Dixon (1977: 56) that if a language has a separate adjective class, it is likely to include members of the dimension, age, value, and color types. The present SA data generally supports this claim, but the overall pattern is not clear-cut. There are interesting exceptions, such as Matsés, in which property concepts denoting dimension are adverbs, on a par with the concepts denoting speed (Fleck 2003: 462).

- Third, and more interestingly, in many sample languages, core members of one semantic type can be heterogeneous. As noted in Dixon (1977: 30), typically all members of a semantic type "have norm association with the same part of speech in a particular language" and that instances when a semantic type is "split between two parts of speech" mainly concern languages with "a very small adjective class”. For SA data, as shown in Table 1, a split in word classes for a semantic type is found in about a quarter of the sample languages. Dixon (2010: 74) mentions the possibility that "main members of a semantic type may belong to different word classes", noting three languages (Yoruba, Hausa and Jarawara) with a limited inventory of true adjectives. It emerges from the SA data that a split between two or even three parts of speech occurs both in languages with a small adjective class and in languages without one. For example, in Urarina, some core property concepts denoting dimension are encoded by verbs and some by nouns (Olawsky 2006: 193). In Tiriyó, the dimension semantic type consists of nominal and adverbial roots (Meira and Gildea 2009). It is noteworthy that antonyms are not necessarily encoded by one and the same word class either. For example, in Mosetén, the property 'good' is encoded by an adjective (jaem'), whereas the property 'bad' is a verb ( $a^{\prime}$ chi-) (Sakel 2004: 143). Urarina has three lexemes for 'big', two of which are stative verbs (tabaa and tasi nohwaa) and the third one is a noun (sẽohwa) (Olawsky 2006: 193). Olawsky (2006: 194-195) observes almost no restrictions in the use of each in a modifier function, but the term tasi nohwaa is less common in this function, with the predicative use being preferred. The semantic distinction is less obvious, but as a tendency there is some preference for use of the sẽohwa term for artefacts, tabaa for nature-related or abstract 
nouns, whereas tasinohwaa is not used with abstract nouns, but unrestricted in use otherwise. Urarina has also two lexemes for 'small', one is a verb, and the other is a noun (Olawsky 2006: 191, 198). Antonyms belonging to different word classes are also found in Baure (see Danielsen 2007: 164).

- Fourth, with respect to antonyms, it is of interest to note that quite a few SA languages have antonym pairs which constitute derivations by either a negative marker or a privative marker ('without'). An equivalent in English would be 'big' versus 'non-big' for 'short'. Example (3) from Mekens illustrates this.

(3)

\begin{tabular}{|c|c|}
\hline Mekens (Tup & ian) \\
\hline ameko & sĩur-ãp \\
\hline dog/jaguar & small-NEG \\
\hline 'big dog' (Lit & 'A dog not small') \\
\hline
\end{tabular}

Besides Mekens, negation as a strategy for antonyms is found in languages of different genealogies: Apurinã (Facundes 2000: 284), Baure (Danielsen 2007: 163), Bora (Miraña) (Thiesen and Weber 2012: 325), Cubeo (Morse and Maxwell 1999: 126), ${ }^{6}$ Southern Aymara (Coler 2014: 157), Sabanê (Araujo 2004: 161), ShipiboKonibo (Valenzuela 2003: 166), Uru (Hannß 2008: 264), Tiriyó (Meira 2000: 105, in Campbell and Grondona 2012: 295), Kanoê (Bacelar and Silva 2003), Pilagá (Vidal 2001: 111), Nivaclé, and in a number of other languages spoken in the Chaco region (Campbell and Grondona 2012: 653). A crosslinguistic exploration of word-level negation to create antonyms is underway (see Koptjevskaja Tamm and Miestamo 2015). The range of different SA languages mentioned above suggests that this is a well-attested phenomenon in South America.

- Fifth, the sample languages show an areal pattern with respect to morphosyntactic characteristics of their property concepts. Languages spoken in the Andean sphere have property concepts that are "nouny" (i.e., share many traits with nouns): Aymaran and Quechuan languages, Leko, Mapudungun, Awa Pit. ${ }^{7}$ This is in strong contrast with the languages of the Amazon region and the Southern Cone, where property concepts are typically encoded by verbs.

- Sixth, while property concepts of the semantic types in (1) are typically encoded by lexical roots, some languages use lexico-grammatical means, such as classifiers, to encode properties related to dimension and physical

6 Also in a closely related language Desano (Silva 2012: 190), which is not in the sample.

7 Cholón, Mochica, Puquina and Kallawaya, which are not part of the sample, provide additional support to the argument. 
properties. We find it mainly among the Arawakan languages of the sample, but also in Cubeo (Tukanoan) and Yagua (Peba-Yaguan). So far, one sample language - Mamaindê (Nambiquaran) - is reported to use classifiers to encode some colors, which is typologically unusual. The use of lexico-grammatical means for the function of attributive modification is further discussed in Section 3.7.

\section{Towards a typology of attributive modification in SA languages}

This section deals with the formal strategies that SA languages employ for the function of attributive modificatiion. A few theoretical preliminaries are in order. An NP can consist either of a single nominal, or of a series of words with a nominal as its central constituent behaving like a single syntactic unit. The term 'nominal expression', used in what follows, is adopted from Reinöhl (2020: 57, following Himmelmann 1997) and Louagie and Reinöhl (this issue) as a neutral term for structures that exhibit loose syntactic structure, but still form a unit semantically, carrying out a single function in discourse. At this point it is also necessary to introduce a number of indicators that can formally signal NP constituency. These include phrase-internal and phrase-external sets of criteria (Louagie and Verstraete 2016; Louagie and Reinöhl this issue). The former can be a fixed constituent order, contiguity, and grammatical agreement marking. The latter set of criteria relate to some formal treatment of constituents as a single structural unit in the clause. These can include boundary markers or phrasal delimiters, prosodic clues, and the occurrence of the constituents as a unit in a particular syntactic position (see also Givón 1995: 177; Meira 1999: 49; Fleck 2003: 755 referring to Radford 1981: 69; inter alia). While information on prosody is often lacking in the sources, making it a hard-to-apply criterion, information on constituent order, contiguity and phrasal morphology (if any) is much easier to obtain. Assigning a relative weight to a criterion does not seem to be useful, and it is rather an interplay of the criteria that (more or less) offers a basis for treating a combination of constituents as one phrase.

I suggest that the typology of attributive modification constructions in SA data reflects a continuum of syntactic complexity: on the one end, we have nominal expressions with a loose syntactic structure ('non-integral' NPs in Rijkhoff's [2002: 19] terminology). On the other end of the suggested continuum, we find attributive constructions that constitute a tight structure at the morphological level. 
In between, there are different types of complex NPs, as well as a simple NP, where constituents show syntactic unithood. The postulated types of constructions are built up from the behavior of individual features signaling constituency.

The observed types of constructions in the present data are as follows:

(i) Nominal expressions ${ }^{8}$ (or non-integral NPs): the referent noun and the constituent denoting a property are a unit on the semantic level, but syntactically there is little evidence for constituency.

(ii) Semi-integral NPs: these differ from nominal expressions (or non-integral NPs) by displaying some syntactic dependency between the two constituents.

(iii) Syntactically complex NP-1: a relative clause or a nominalization construction.

(iv) Syntactically complex NP-2: structurally identical to a possession construction. This involves formal marking of a relationship between the modifier (i.e., a property-denoting constituent) and its head as for possession.

(v) Simple NP: juxtaposition of the modifier (i.e., a property-denoting constituent) and its head, forming a tight two-constituent NP. This involves property concepts that are morphologically underived but may (but need not) be inflected.

(vi) Compound: a semantic modifier (i.e., a property-denoting constituent) and its semantic head form a compound. This involves property concepts that are expressed by bound roots, i.e., roots that cannot occur independently.

(vii) Derived noun: a semantic modifier (i.e., a property-denoting element) is encoded by a bound element with a semi-grammaticalized synchronic status, differing from bound roots above by carrying a less specific meaning. The resulting product can be ambiguous between a compound and a derived noun.

A language may have one particular dominant construction for attributive modification. This is the case when property concepts in a language are morphosyntactically homogeneous across and within semantic types. However, in many sample languages multiple constructions are in use, and, interestingly, the variation in construction can be found at the level of individual lexemes. For example, while some property concepts in Movima form a compound with the head noun, and some require a syntactically complex NP (relative clause), there are two lexemes (mere' 'big' and tochi' 'small') that occur in juxtaposition with the head noun (Haude 2006: 116), adhering to a construction analyzed here as a simple NP.

8 Louagie and Reinöhl (this issue, following Himmelmann 1997) refer to this construal type as a 'nominal group'. 
Appendix 2 gives an overview of attributive constructions which I identified in the sample languages. The following Sections (3.1-3.7) illustrate and motivate each construction type by examining the clues for constituency and their interplay within a language. For this purpose, I zoom in on a selection of sample languages.

Before we turn to the discussion, it is important to draw attention to the fact that far from all SA languages allow the attributive use of property concepts (see also Krasnoukhova 2012: 158). Among the languages in which attribution is possible, quite a few show a strong preference towards the predicative use of property concepts and an aversion to their use as attributive modifiers. This is reported for languages of different genealogies, viz. Aguaruna (Overall 2012, 2017: 217), Apurinã (Facundes 2000: 343), Baure (Danielsen 2007: 168), Mojeño Trinitario (Rose in prep., p.c.), Akwẽ-Xerente (Sousa Filho 2007 : 221), Krenak (Pessoa 2012: 216), Mamaindê (Eberhard 2009: 364), Movima (Haude 2006: 114), Wari' (Joshua Birchall, p.c.), Yurakaré (van Gijn 2006: 92), Mawetí- and Tupi-Guaraní languages in general (Queixalós 2006: 253; Rose forthc.), Cariban languages (Sergio Meira, p.c.), Ese Ejja (Vuillermet 2012: 323), and Cavineña (Guillaume 2008: 465). Besides, for many other languages, examples often comprise predicatively used property concepts rather than their use as modifiers. The fact that property terms in many SA languages are verbal in nature, further suggests that their default function is predication rather than modification. In the sample, about a quarter of the languages (17 out of 65) seem to use the predicative strategy as the preferred one or the only available (see Appendix 2).

Nevertheless, attributive modification is possible in many sample languages, as discussed next.

\subsection{Nominal expressions ('nominal groups' or non-integral NPs)}

This type of construction involves two constituents which form a unit semantically, but the syntactic bond is loose. The latter is evidenced from such characteristics as a flexible relative order, non-contiguity, phrasal morphology appearing on each individual constituent instead of a single phrase-final position, and prosody. Each constituent typically forms a referring expression by itself (see Rijkhoff 2002: 19, 22), but it seems possible to say that one constituent conveys information about the other, thus, in a sense, there is some restriction of reference at play. Obviously, for non-integral NPs one cannot speak of a 'head' and a 'modifier' sensu stricto. I adopt Rijkhoff's (2002: 22) term ‘appositional modifier' as a proxy for a constituent 
that involves a property concept, and I will use an analogous term, 'appositional head', for a constituent which is the head semantically. ${ }^{9}$

Nominal expressions in the sense outlined above have been reported for the languages of the Cariban family (Meira and Gildea 2009). An 'appositional modifier' and an 'appositional head' are "pragmatically assumed to refer to the same realworld entity” (Meira and Gildea 2009: 114). Property concepts as in (1) are encoded mainly by nouns and adverbs in this family. In many, if not most, Cariban languages these are syntactically independent constituents (Meira and Gildea 2009: 116). One piece of evidence for their syntactic independence is the lack of obligatory contiguity and constraints on constituent order: a property term can either precede the 'appositional head' (4a) or follow it (4b) or be non-contiguous with it (4c). Another piece of evidence that the constituents do not form a syntactic unit is prosody. For example, in Hixkaryana (5) and Macushi (6) there is typically a pause in between (Abbott 1991: 70; Meira and Gildea 2009: 114), indicated in the examples with a comma.
Tiriyó (Cariban)
a. o:ni po nai, kura-no eperu, әmija-n eperu marə, ti-ka-e that LOC 3.COP good-NMLZ fruit soft-NMLZ fruit too PST-say-PST ' “Over there (there) are good fruits, soft fruits too," (he) said.' (Meira and Gildea 2009: 114)
b. konopo mono n-e:-jan 'Big (=a lot of) rain is coming.' (Meira and Gildea 2009: 115) rain big.one 3s-come-PRS
c. kure irə j-ekeima-to o-ija, kura-no w-ekeima ə-emi good this 1-do.evil-c.nMLz 2-AGT good-nMLz 1A-do.evil.PST 2-daughter 'It is OK that you want to do evil to me, (for) I have done evil to your good daughter.'

(Meira and Gildea 2009: 114)

(5) Hixkaryana (Cariban)

hi:... ka-je hati, wajamo, wosi
all.right say-PST HRSY turtle
" "All right..." said the turtle, the woman/female (turtle).'
(Meira and Gildea 2009: 115)

\footnotetext{
9 It should be mentioned that the term 'apposition' is used for a variety of constructions (see also Rijkhoff 2002: 22 referring to Matthews 1981: 224-236; Heringa 2011: 1; Louagie and Reinöhl this issue). As Rijkhoff (2002: 22) also observes, whenever the term is used in grammatical descriptions it usually remains undefined. The common line, however, is that 'apposition' typically refers to constituents that are referring expressions that belong together semantically but not syntactically.
} 
Meira and Gildea (2009: 114) suggest that constraints on constituent order may be emerging in Macushi, where the 'appositional modifier' would precede the 'appositional head'. However, these scholars also note that there is no phonological or morphological evidence for phrasal unity. In an earlier account of Macushi by Abbott (1991: 31, 70, 87-88) no constituent order constraints are observed, and constituents are noted to frequently "occur in a discontinuous sequence" (Abbott 1991: 70). Furthermore, such nominalized constituents usually occur with an intonation break (Abbott 1991: 70), in accordance with Meira and Gildea. Example (6) shows a property term a'ne' 'hot one', which follows its 'appositional head'. The constituents are separated by a pause, and each takes a postposition.

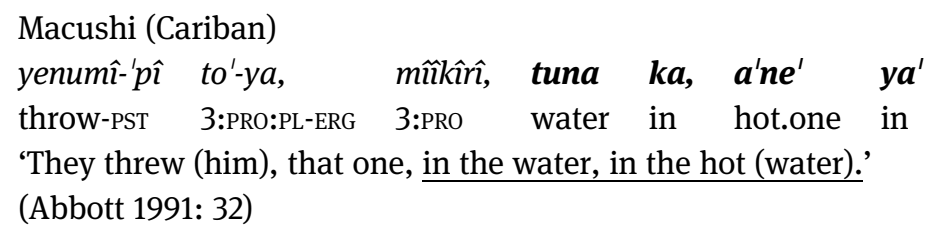

Besides the Cariban languages, there are a few other languages in the sample in which attributive modification can be analyzed in terms of nominal expressions. This mainly concerns languages spoken in the Western and South-Western part of the Amazon, which possess rich inventories of classifiers, often of the 'multifunctional' type (Krasnoukhova 2012: 194). The classifiers in question combine a number of functions: semantic categorization, the function of derivation, and referential function (Payne 1987; Derbyshire and Payne 1990; Aikhenvald 2000; Grinevald and Seifart 2004; Seifart and Payne 2007; inter alia). Typically, such classifiers occur in 'multiple environments' (Aikhenvald 2000), viz. on numerals, nouns, verbs and - most relevant in our case - on roots denoting properties. Doris Payne (1987: 39) suggests that reference tracking may be the primary function of classifiers in these languages. Payne specifies that classifiers "may be used to avoid full noun phrases and expanded noun phrases in particular" (1987: 39). Concretely, when a classifier occurs "in any syntactic context (numeral, demonstrative, attributive modifier, predicate nominal, or another noun), it indicates sufficient features of the referent such that a more specific head noun may not be pragmatically necessary in a given context” (Payne 1987: 39). Let us take Bora for illustration. Example (7) shows a few different uses of the root imi denoting 'good'. In (7a), 'good' is the predicate, evidenced from its high tone on both syllables, and the $?$ ending (Thiesen and Weber 2012: 225). In (7b) 'good' is an adverbial modifier of the predicate 'to sleep'. In (7c), 'good' functions attributively, always taking a classifier (Thiesen and Weber 2012: 224, 226; Seifart 2005). Attributive constructions such as (7c) are analyzed by Thiesen and Weber (2012: 225) as two NPs in apposition (see also Seifart 2005: 150-156). 
(7) Bora (Boran)

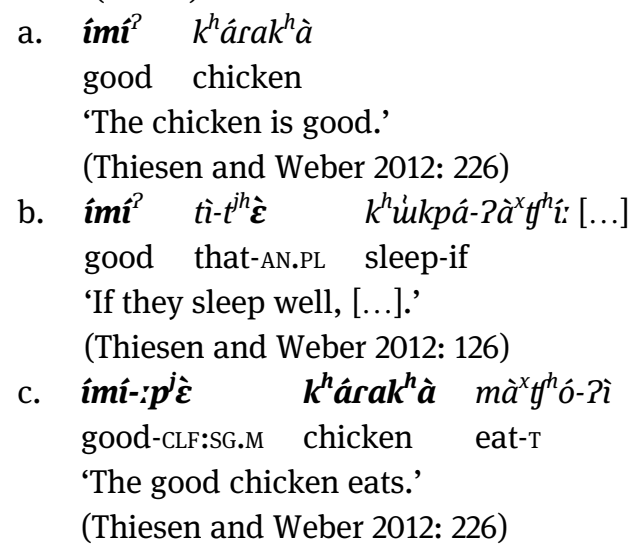

Property roots combined with a classifier, like those in (7c) and (8), form referential expressions by themselves, with the classifier functioning as the head. Specifically, classifiers in Bora are nominal elements, and some have corresponding free nouns (Seifart 2005; Thiesen and Weber 2012: 182). Classifiers can stack, as shown in (8a), and it is the final classifier in that case that sets "the semantic domain within which the referent is to be found" (Thiesen and Weber 2012: 179). This is an indication that classifiers head their phrases. Just like noun roots, classifiers in Bora can denote and refer to "objects that prototypically can be localized in space and persist over time" (Thiesen and Weber 2012: 184). A difference between noun roots and classifiers is that the former have specific meanings, whereas the latter have less specific meanings (Thiesen and Weber 2012: 184).

\section{Bora (Boran)}

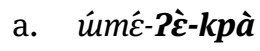
tree-cLF:tree.like.plant-cLF:long.flat.rect

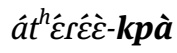
'a worthless plank' (Thiesen and Weber 2012: 174) ${ }^{10}$

b. $\varepsilon:-h \boldsymbol{i}$ múhu-hi kú:Cubeomu-hi DEM:DIST-CLF:2D.round be.big.suB-CLF:2D.round turtle-CLF:2D.round 'that big turtle' (Seifart 2005: 169)

10 The classifiers - $-\grave{\varepsilon}$ and -kpà are glossed in the source material as - $-\grave{\varepsilon}$ 'tree' and -kpà 'slab', which is the meaning of the context. I use a gloss that is provided in the description of these classifiers: $-P \grave{\varepsilon}$ 'botanical: a tree or a tree-like plant' (Thiesen and Weber 2012: 454) and -kpà 'shape: long, flat and roughly rectangular' (Thiesen and Weber 2012: 462). 
Seifart (2005: 151) notes that even when appositional NPs occur adjacent to each other and one NP restricts the reference of the other, they show "a high degree of syntactic independence”. The following pieces of evidence suggest this (see also Thiesen and Weber 2012: 190, 223):

- Any noun phrase can be omitted.

- Case markers, the restrictive marker, clitics, or even other words, can intervene between noun phrases in apposition.

- The order of the noun phrases in apposition is relatively free.

- Noun phrases in apposition always form separate tonal phrases.

- There is often a prosodic break (e.g., a pause) between the noun phrases in apposition.

(Seifart 2005: 151).

We see a similar phenomenon in other languages with multifunctional classifiers. Example (9) is from Cubeo. Some attributive structures in Cubeo show signs of constituency (e.g., variable order, although with a certain tendency and oblique case markers occurring only at the phrase boundary) and may thus be analyzed as semi-integral NPs (like Kwaza in Section 3.2).

Cubeo (Tukanoan)

kĩrã-xĩ-bo

bo-RI-xĩ-bo

stone-DIM-CLF:small.round be.white-NMLZ-DIM-CLF:small.round

'a small white stone'

(Morse and Maxwell 1999: 126)

While there is a good amount of evidence to analyze property roots used attributively in Bora (and probably in some cases in Cubeo) as nominal expressions, i.e., nonintegral NPs, one can note two features which, at first sight, seem to contradict this analysis. First, the NP with a property term constitutes a relative clause, formally marked by tone as subordinate (Seifart 2005: 133). However, the fact that a relative clause constituent can stand on its own, and that no further clues of syntactic dependency can be observed (see Seifart 2005: 155) suggests that a constituent involving a property concept is syntactically independent. Second, the use of classifiers on all constituents, as in (8) and (9), can be taken as a form of grammatical agreement and thus syntactic dependency between the constituents. However, a true agreement system typically involves a division of all nouns into rigid classes and shows an obligatory and predictable occurrence of an inflectional marker. As shown by Seifart (2005), classifiers in Bora primarily function to establish coreference in discourse and not to mark syntactic structures. For example, there is some alternation possible in the choice between so-called general and specific classifiers within one clause, which rather depends on "the degree to which a speaker wishes to specify a referent at a given point in discourse" (Seifart 2005: 172). Furthermore, it is the derivational capacity of classifiers (viz. their capacity to add 
Table 2: Characteristics of nominal expressions in Hixkaryana, Macushi, and Bora.

\begin{tabular}{lllllll}
\hline & $\begin{array}{l}\text { Fixed } \\
\text { relative } \\
\text { order }\end{array}$ & $\begin{array}{l}\text { Adjacency } \\
\text { required }\end{array}$ & $\begin{array}{l}\text { One } \\
\text { prosodic } \\
\text { unit }\end{array}$ & Co-referring & $\begin{array}{l}\text { Referent } \\
\text { noun } \\
\text { obligatory }\end{array}$ & $\begin{array}{l}\text { Grammatical } \\
\text { agreement }\end{array}$ \\
\hline Hixkaryana & - & - & - & + & - & - \\
Macushi & $+/-$ & - & - & + & - & - \\
Bora & - & - & - & + & - & $+/-$ \\
\hline
\end{tabular}

semantic content) that ensures referent identification and syntactic independence from the referent noun (see Seifart 2005: 173-174).

Table 2 gives a summary of characteristics of nominal expressions discussed in this section.

In Bora and in the Cariban languages, nominal expressions constitute the only available strategy for attributive modification. In Rießler's (2016) world-wide (although unbalanced) sample, only one language out of 71 is of this type, viz. Cariban Hixkaryana. In Rijkhoff's (2002: 133, 138) sample, this is the case for two out of 52 languages (Nunggubuyu in Australia and, again, Hixkaryana in South America). While it may be a consequence of the samples used, such a rare occurrence suggests that relying exclusively on nominal expressions is typologically relatively uncommon. Tukanoan Cubeo and Kotiria constitute cases where attributive constructions involve a mix of those with characteristics of nominal expressions and those with some signs of constituency. Furthermore, nominal expressions are also found in languages that do have simple integral NPs for attributive modification (e.g., Matsés, Hup, Southern Aymara).

\subsection{Semi-integral NPs}

In some languages with multifunctional classifiers, the NPs can display some characteristics of syntactic unithood. Cubeo and Kotiria were already mentioned as possible cases. I will illustrate the category with Kwaza though, as the relevant variation is more evident. Property concepts in Kwaza are encoded by verbal roots, and these must be nominalized to occur attributively. Nominalization can be done either by a semantically neutral classifier (10a) or by a specific classifier (10b) (van der Voort 2004: 181, 2006). The inventory of classifiers ranges from etymologically opaque to etymologically transparent ones, and some classifiers are more semantically specific than others (van der Voort 2004: 137-176). Referent nouns are regularly omitted when specific classifiers are used, as "most classifiers display a predictable meaning in most constructions" (van der Voort 2004: 176). As 
shown in (10b), the referent (a'xy 'house' in this case) can be omitted, since the property root occurs with a classifier that is semantically specific enough. Example (10a), which shows the neutral classifier -'hỹ, can also occur with the specific classifier -'xy for 'house', in which case the referent noun can be omitted (Hein van der Voort p.c.). (10c) and (10d) illustrate a full NP construed by another specific classifier: -'mũ, which refers to juice, lemonade or fermented beer or the like. This particular classifier comes from the lexical form e'mũ 'liquid' (van der Voort 2004: 157).

(10) Kwaza (unclassified)
a. a'xy arwa-'hỹ
house be.new-NMLz
'new house'
(van der Voort 2004: 131)
b. (a'xy) haka-'xy
'old house'
(house) be.old-cLF:house
(van der Voort 2004: 131)
c. $\quad a w y$-'mũ
be.cold-CLF:liquid
'cold liquid'
(van der Voort 2004: 131)
d. jo-'mũ
manioc-CLF:liquid
'manioc beer'
(van der Voort 2004: 134)

Examples (10a) and (10b) each contain two NPs, viz. 'house' and 'new/old house'. A head and a modifying constituent usually occur contiguously; however, there are also cases when a predicate occurs in between (Hein van der Voort p.c.). The order of constituents in attributive constructions is usually 'head'-'modifier', but it can also be reversed (van der Voort 2004: 104, van der Voort 2006: 90). While both constituents are referring expressions on their own, they seem not to exhibit the same amount of syntactic freedom as those in Bora. Based on these characteristics, I treat constructions that involve semantically specific classifiers in Kwaza (as 10b) as 'semi-integral' NPs. Constructions that involve semantically neutral classifiers (as 10a) seem to show even stronger characteristics of an integral NP: the fact that the referent noun cannot be omitted suggests that we have a construction with some syntactic dependency and structure. The modifying constituent with a semantically neutral classifier serves for a restriction of reference rather than for reference itself (Hein van der Voort, p.c.). Therefore, I suggest that attributive constructions with property concepts in Kwaza range from those with weaker 
Table 3: Characteristics of attributively used property roots in Kwaza.

\begin{tabular}{lllllll}
\hline Kwaza & $\begin{array}{l}\text { Fixed } \\
\text { relative } \\
\text { order }\end{array}$ & $\begin{array}{l}\text { Adjacency } \\
\text { required }\end{array}$ & $\begin{array}{l}\text { One } \\
\text { prosodic } \\
\text { unit }\end{array}$ & $\begin{array}{l}\text { Co- } \\
\text { referring }\end{array}$ & $\begin{array}{l}\text { Referent } \\
\text { noun } \\
\text { obligatory }\end{array}$ & $\begin{array}{l}\text { Grammatical } \\
\text { agreement }\end{array}$ \\
\hline $\begin{array}{l}\text { Property root }+ \\
\text { Specific CLF }\end{array}$ & $+/-$ & $+/-$ & $?$ & + & - & - \\
$\begin{array}{l}\text { Property } \\
\text { root + neutral } \\
\text { CLF }\end{array}$ & $+/-$ & $+/-$ & $?$ & - & + & - \\
\hline
\end{tabular}

evidence for one integral NP to those with stronger evidence for it. More generally, it illustrates that a language does not necessarily have one particular type of NP in terms of constituency and could be seen as a system in flux.

Table 3 gives a summary of characteristics of attributively used property roots in Kwaza with either specific or semantically neutral classifiers.

Sample languages with rich of classifier inventories and thus showing a similar profile with respect to attributive modification (Tariana, Yagua, Mako, Kanoê, Cubeo, and Kotiria) are concentrated geographically in the Northwest Amazon (Payne 1987; Derbyshire and Payne 1990; Aikhenvald 1996: 84, 86; Seifart and Payne 2007) and in the Southwest Amazon region (van der Voort 2005). Thus, attributive modification relying on structures such as nominal expressions and semi-integral NPs can be suggested as one of the areal traits.

\subsection{Complex NP: relative clause or nominalization}

As shown in Table 1, in many SA languages property concepts are encoded by verbal roots. In many of these languages such verbal roots can occur as modifiers when nominalized or used as part of a relative clause. In SA, nominalization is a common strategy for dependent clause marking, including relative clause formation (van Gijn 2014). Kukama-Kukamiria is an example. (11a) shows a property concept ('be white') which is encoded by a verbal root taking the nominalizer $-n$ (see also (2) above). (11b) illustrates the same nominalizer for a relative clause formation with an active verb. A nominalized relative clause can occur before or after the head noun (Vallejos 2016: 468-469). However, no pauses or intervening material can occur between the head noun and the nominalized verb (Rosa Vallejos p.c.). Besides, if we were to add a quantifier to (11a), it would appear before the head noun and would extend its scope to the nominalized verb (e.g., 'a lot of white clay') (Rosa Vallejos p.c.). 
(11) Kukama-Kukamiria (Tupian)
clay be.white-nmLz jar remedy
'The white clay is the jar's remedy (can be used to seal jars)'.
(Vallejos 2016: 241)
a. tawa tini-n muritsu mutsana
b. tsa=mimira yawara karuta-n=chasu=pura
1SG.FS=son.female.ego dog bit-NMLZ=AFF=FOC
'My son whom the dog bit...'
(Vallejos 2016: 456)

Besides nominalization, some languages use a relative clause construction with a relative clause marker. As a result, attributive modification constructions constitute (minimal) relative clauses. This is shown in (12) for Bororo. The relative clause marker wü is always the final element of a relative clause (Crowell 1979: 109; Nonato 2008: 142). ${ }^{11}$ Relative clauses that involve property terms can either precede or follow the noun they modify, with no difference in meaning; the latter order, however, is noted to be more common (Crowell 1979: 112; Nonato 2008: 144). Example (12a) illustrates the predicative use of the property concept 'be good'. In (12b) the same property term is part of a relative clause (marked by the relativizer wü) that functions as a modifier of the referent noun 'fish'. Note that the referent 'fish' is plural: the noun itself is in plural form, it is also marked by the plural marker ge following the relative clause, and the transitive verb 'kill' takes the plural object prefix. As (12b) also shows, the subject prefix on the verb in the relative clause (viz. on the property root) is always singular, regardless of the number of the referent (Crowell 1979: 109; Nonato 2008: 144).

(12) Bororo (Bororoan)

a. ø-ro-re

3sG-be.good-ASR

'It is delicious.'

(Nonato 2008: 143)
b. a-re ia kare [ø-ro-re wï] ge e-bitö
2SG-ASR some fish.PL 3sG-be.good-ASR REL PL 3PL-kill
'You caught delicious fish.' (Lit. "You caught fish which are
delicious.”)
(Nonato 2008: 143)

11 The relative marker wü is clearly related to the four demonstrative pronouns awü, nowü, cewü and jewü, which encode different distance degrees (Nonato 2008: 58). Adnominal demonstratives usually precede the head noun (Nonato 2008: 57). 
Table 4: Characteristics of property roots in Kukama-Kukamiria and Bororo.

\begin{tabular}{|c|c|c|c|c|c|c|}
\hline & $\begin{array}{l}\text { Fixed } \\
\text { relative } \\
\text { order }\end{array}$ & $\begin{array}{l}\text { Adjacency } \\
\text { required }\end{array}$ & $\begin{array}{l}\text { One } \\
\text { prosodic } \\
\text { unit }\end{array}$ & Co-referring & $\begin{array}{l}\text { Referent } \\
\text { noun } \\
\text { obligatory }\end{array}$ & $\begin{array}{l}\text { Grammatical } \\
\text { agreement }\end{array}$ \\
\hline Kukama-Kukamiria & - & + & + & $?$ & + & - \\
\hline Bororo & - & $+(?)$ & $?$ & $?$ & $+(?)$ & - \\
\hline
\end{tabular}

There is no information about prosody for the relative clauses in Bororo. It is not clear if the occurrence of the relative clause marker can be taken as an indication of syntactic dependency between a relative clause and its head noun. Adjacency of the two constituents seems to be required, just as the presence of the referent noun. I tentatively treat this construction as a complex but integral NP.

Table 4 is a summary of characteristics of property roots in Kukama-Kukamiria and Bororo.

A complex NP construction involving either a relative clause or a nominalization is found in 18 sample languages. In 12 languages of these languages, this is the only strategy. Attributive modification realized either by nominalizations or relative clauses is common crosslinguistically, adhered by languages in which property concepts are encoded by verbs.

\subsection{Complex NP: as a possessive construction}

Another complex NP construction for attributive modification is formally identical to the one encoding inalienable possession. It is known from typological studies that some languages do not differentiate between modification by property terms and alienable possession (Gil 2013), and in some languages there is no formal difference between modification by property terms and inalienable possession (Nikolaeva and Spencer 2019: 77). In some languages the shared strategy involves a simple juxtaposition of two unmarked constituents. The construction that I am concerned with in this section involves a morpho-syntactically complex NP: the two constituents are linked by a morphological marker.

Consider Wari'. In this language, some property concepts are argued by Everett and Kern (1997) to be encoded by nouns and some by verbs. When properties encoded by nouns are used attributively, the construction is formally identical to the one marking possession (Everett and Kern 1997: 332): the constituent encoding the possessed entity takes a possessive marker (either a suffix or a clitic), which inflects for person, number and gender of the possessor (Everett and 
Kern 1997: 229-230). It must be mentioned that the occurrence of property concepts as modifiers is much less frequent than their occurrence as predicates (Joshua Birchall, p.c.). If a property term does occur as modifier, the first nominal takes a possessive marker (Everett and Kern 1997: 332). The relative order of the head and the modifier is fixed.

Wari' (Chapacuran)
a. xiri-con Xijam
house-3SG.M N.PROP
'Xijam's house'
(Everett and Kern 1997: 147)
b. wijima-in xirim
smallness-3N house
'small house' (Lit: 'the house's smallness')
(Everett and Kern 1997: 148)
c. 'An 'ina-on xocori-con wom
take:SG 1sG:RP/P-3SG.m newness-3sG.m cotton
'I got a new dress.' (Lit. '...dress's newness')
(Everett and Kern 1997: 333)

It is of interest to note that the semantic and syntactic dependency between the attributive modifier and the head is reversed here (see also Rießler 2016: 37). Rießler (2016: 38) offers the following analysis of such constructions: "the semantic dependent is 'upgraded' to the function of the syntactic head of the phrase, i.e., the possessed", whereas the semantic head is "syntactically 'degraded' to the (dependent) possessor function”. In the next section I show that Hup allows a similar strategy, although in Hup it is not the only strategy for attributive modification.

Table 5 is a summary of characteristics of property roots in Wari'.

In the present sample, this construction is found only in two languages (Wari' and Hup), suggesting its relative infrequency in South America. While Hup allows also simple NPs, this is not the case for Wari' (and where the general preference goes to a predicative use of property terms). In Rießler's (2016: 254) world-wide sample, only two out of 71 languages use the possessive construction for property modification: Saliba (Oceanic) and Wari. This strategy seems pervasive in Oceanic languages though (Rießler 2016: 38, referring to; Ross 1998).

Table 5: Characteristics of property roots in Wari'.

\begin{tabular}{|c|c|c|c|c|c|c|c|}
\hline & $\begin{array}{l}\text { Fixed } \\
\text { relative } \\
\text { order }\end{array}$ & $\begin{array}{l}\text { Adjacency } \\
\text { required }\end{array}$ & $\begin{array}{l}\text { One } \\
\text { prosodic } \\
\text { unit }\end{array}$ & Co-referring & $\begin{array}{l}\text { Referent } \\
\text { noun } \\
\text { obligatory }\end{array}$ & $\begin{array}{l}\text { Grammatical } \\
\text { agreement }\end{array}$ & $\begin{array}{l}\text { Phrase- } \\
\text { internal } \\
\text { marker }\end{array}$ \\
\hline Wari' & + & + & $?$ & $?$ & + & - & + \\
\hline
\end{tabular}




\subsection{Simple NP}

Constructions that are subsumed under 'simple NP' involve two constituents that are morphologically underived and form one syntactic unit. The indications for unity include obligatory contiguity and fixed constituent order, phrasal markers, grammatical agreement between the two constituents, obligatory presence of the head, and finally, prosodic clues.

A simple NP can be found in Cavineña. The language has two types of property terms: (i) a small number of property terms which are used attributively with no morphological modification, and (ii) a large (and open) number of properties that mainly occur predicatively. The latter can be used as modifiers when relativized. An example of a property term of the first type is shown in (14). Both the head noun and the modifier form one phrase, since (a) nothing can intervene between the two constituents (Guillaume 2008: 466) and (b) a phrasal clitic - in this case, the locative marker $=j u-$ occurs on the final constituent of the NP.

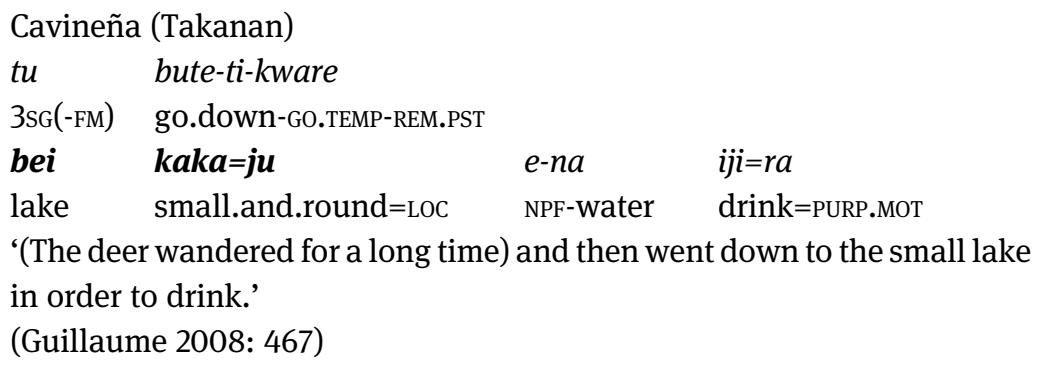

Property terms of the first type never occur on their own and obligatorily require a head noun (Guillaume 2008: 466). In fact, the strength of the bond between these constituents even calls for an alternative analysis in terms of compounding (Guillaume 2008: 474). However, Guillaume (2008: 474) prefers to treat attributively used property terms as independent modifiers. The reason is that attributively used properties can have an independent pitch contour, and even a pause is possible between the head noun and the modifying property. Besides, at least some property terms are productive: when combined with a noun the compositional meaning is transparent (Guillaume 2008: 474). In Section 3.6, we return to attributive constructions that constitute compounds (note, however, that non-compositional semantics will not be presupposed as a central feature of such compounds).

It is also the case that property terms can resemble (inalienably) possessed nouns. Take Hup as an example. Property concepts denoting dimension, age, value and color belong to a separate adjective class, although they share some characteristics with both nouns and verbs (Epps 2008: 114, 442). These property terms can modify a noun directly with no additional morphology, forming a clear syntactic unit: the modifier follows the head, phrasal markers (viz. plural and case markers) 
attach to the final constituent, and phonologically they are treated as "a single lexical unit, with primary stress on the second constituent” (Epps 2008: 328, 326, 187). Example (15) illustrates the point.

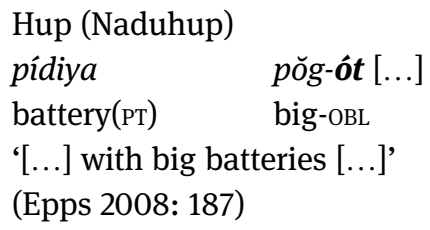

However, these property terms must always be preceded by some nominal form. In (15) it is the noun (pídiya 'battery'). To occur independently property terms have to take the preform $t$ th $=$, which is a 3rd person singular pronoun (Epps 2008: 327). This preform tih $=$ has a nominalizing function, evidenced by a number of behavioral characteristics (for example, property terms with the preform are negated by a nominal negator instead of a verbal one) (Epps 2008: 332). An attributive construction can also consist of the head noun and a property term preceded by the preform, viz. $[\mathrm{N} \text { t th }=\mathrm{A}]^{12}$. This construction is illustrated in (16a). Similar to cases discussed in Section 3.4, this construction can show characteristics of one complex but integral NP, evidenced from the presence of a single phrasal marker and the absence of a pause between the constituents (Epps 2008: 332). However, these elements can also behave as a nominal expression (i.e., non-integral NP), similar to cases discussed in Section 3.1. This is seen from the fact that each constituent can take phrasal morphology. The latter is illustrated in (16b), where the object marker -ăn can occur on the noun ('man') when the modifier ('big') carries the preform $t$ th $=$ (Epps 2008: 180).

Hup (Naduhup)

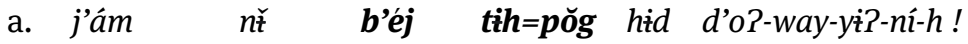
yesterday 1sG.POS jandia 3sG=big 3PL take-go.out-TEL-INFR-DECL 'Yesterday they took out my big jandia fish!'

(Epps 2008: 333)

b. tiy̌rì(-ăn) (tỉh=)pǒg-ăn túk-úy=mah man-oBj 3SG=big-oBJ want-DYNM-REP

'She likes the big man, it's said.'

(Epps 2008: 180)

Thus, Hup allows for at least three types of attributive construction with property terms: a simple NP, a complex integral NP, and a non-integral NP. As noted by Epps (2008: 332) speakers judge the constructions [N tih $=\mathrm{A}]$ and $[\mathrm{N} A]$ to be interchangeable, but there is some semantic difference. The former seems to place

12 'N' stands for 'noun', 'A' for 'adjective'. 
the property or quality in focus and indicate a quality that is permanent or inherent. The latter construction may indicate a quality which is either permanent or temporary (Epps 2008: 332). Whereas the preform is not obligatory, some color terms are observed to almost always occur with it, and a few property concepts, such as tuhúp 'beautiful, new', and tidó 'red', have even undergone phonological reduction (Epps 2008: 333).

The construction [N $t \dot{t} h=\mathrm{A}]$ is similar to the ones we saw in Section 3.4 in Wari'. Syntactic clues for headedness are few in Hup, but it is possible to analyze the property term as the head and the preform as the modifier (Epps 2008: 329-330). While the preform is a personal pronoun in origin, synchronically in this context it functions as a nominalizer and a marker of inalienable possession, and also as a linker, signaling the relationship between the head and the modifying constituent (Epps 2008: 333, p.c.). Epps (2008: 328-329) notes a formal resemblance between property terms with $t$ th $=$ and bound (and inalienably possessed) nouns. While synchronically the two constructions show some differences, Epps (2008: 331, 333) suggests that these constructions are very likely to be historically and/or functionally related. In fact, the use of $t \dot{t} h=$ with property terms is likely to be an extension of its use with bound nouns, which probably did emerge in inalienable possession constructions (Patience Epps, p.c.). Epps (2008: 333) also raises the question of a possible further development of the preform into an attributive marker, ${ }^{13}$ which finds support crosslinguistically.

In this light it is of interest to briefly illustrate attributive constructions found in Macro-Ge. First of all, it should be mentioned that studies on Macro-Ge show some disagreement on the analysis of property terms as belonging to the category of verbs or the category of nouns. This is due to the fact that the two categories have a number of features in common (Oliveira 2003: 244; Ribeiro 2012: 212-214; inter alia). Among the features shared between nominal and verbal roots in Macro-Ge is the occurrence of a so-called 'relational prefix' ${ }^{14}$ Existing analyses of its function are not uncontested among Macro-Ge specialists. According to Rodrigues (1999: 181), it functions as a linker, i.e., an indicator of "textual contiguity", marking the head of a nominal, verbal and postpositional phrase. Rodrigues (1999: 181) notes that "[t]his device must be a very old one in the Macro-Ge stock"; in some languages of the family it is a

13 Patience Epps (p.c.) proposes that the historical process would include the following steps: tih $=$ as possessor (with nouns) > dummy head noun (with nouns and property terms) > (maybe?) linker/ attributive marker (with property terms).

14 A 'relational prefix' is noted to be a feature of Cariban languages (Gildea 1998: 113) and Tupian languages (Rodrigues 1999:181, Rose forthc., inter alia). However, for Tupian relational morphology has been disputed. For example, Meira and Drude (2013) argue that it is not a prefix but a phonologically conditioned part of the stem, and Payne (1994, referred to in Rose, forthc.), proposes that it is an inverse marker. 
disappearing system with very restricted occurrences. The actual forms of relational prefixes differ among the Macro-Ge languages. Some languages have different allomorphs of the relational prefix, and its occurrence can be phonologically conditioned. For example, in Apinajé, a relational prefix occurs only on vowel-initial roots (Oliveira 2003: 268, 2005: 182-190, 197). ${ }^{15}$ What we find in Macro-Ge is a constructional parallel between attributively used property terms and inalienable possession, and the reverse semantic and syntactic dependency - just like in (13) from Wari' (and possibly in (16a) in Hup). The head of a phrase always follows its dependents, and it is the head that occurs with a relational prefix (Rodrigues 1999: 181; Oliveira 2003: 269). Example (17) from Canela-Krahô, a Northern Ge language, and (18) from Karajá, a language forming its own branch within the Macro-Ge stock, illustrate constructions with a relational prefix. One could have treated these constructions on a par with possessive constructions in Wari (Section 3.4); however, since a relational prefix functions as a contiguity marker, not limited to possessive constructions, I discuss these constructions in this section.

(17) Canela-Krahô (Macro-Ge)

a. ko j-urore

water R-shallow

'the shallows of the water; shallow water' [Orig.: 'o raso da água; água rasa'] (Miranda 2014: 74)

b. Hakwaj j-ĩak ${ }^{h} r \varepsilon$

N.PROP R-nose

'Hakwəj's nose' [Orig.: 'nariz de Hakwəj']

(Miranda 2014: 71)

(18) Karajá (Macro-Ge)

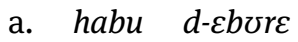

man R-angry

'man's anger; angry man'

(Ribeiro 2012: 216)

b. $d z-u \quad d-\varepsilon \theta \varepsilon$

R-tooth R-pain

'tooth ache'

(Ribeiro 2012: 215)

Discussing relational prefixes in Apinajé, Oliveira (2003: 251-252) mentions that "[i]t is possible that these forms are old third-person morphemes", and

15 Apinaje is not part of the present sample, it belongs to the Northern Ge branch just as CanelaKrahô, which is included in the sample. 
synchronically, if present, "they are a strong and systematic indicator of constituency". However, since a relational prefix can be absent on some roots, the issue of constituency does seem to arise. We discuss this issue in Section 4.

Table 6 gives a summary of characteristics as discussed for Cavineña, Hup and Canela-Krahô.

Attributive modification having a structure of a simple integral NP is possible in 28 out of 65 sample languages. While in 19 of these languages the simple integral NP seems to be the only or the main strategy, the other nine languages use additional strategies for attributive modification. We can conclude that a construction of a simple NP is far from being a dominant (or typical) strategy for attributive modification in SA languages.

\subsection{Attributive modification as compounding}

In some SA languages the function of modification is carried out by property terms which morphologically constitute bound roots. An attributive construction has a structure of a complex word or a compound. A definition of compounding from a crosslinguistic perspective remains a challenge, with Lieber and Štekauer (2009) devoting a whole chapter to this problem. Compounds usually involve lexemes (Bauer 2009: 343), but in many SA languages spoken in the Western and SouthWestern Amazon, it is hard to draw a line between bound lexemes and 'lexicogrammatical' elements, ${ }^{16}$ viz. classifiers. Thus, I will use the term 'compound' in a loose sense: it will refer to a combination of roots, one of which can have a semigrammatical status, yielding a morphologically complex noun which constitutes one phonological word. Note that the present term does not presuppose noncompositional semantics. I will now discuss constructions of attributive modification that arguably involve compounding as discussed above.

Consider Arawakan Baure. In Baure, some property concepts denoting dimension, age and value are encoded by nominal lexical roots which cannot occur in isolation (Danielsen 2007: 156). When modifying an obligatorily possessed noun, the two elements form a compound.

Baure (Arawakan)

a. cho-po'e

big-head

'big head'

(Admiraal and Danielsen 2014: 94)

16 The term is due to Grinevald (2000: 61). 


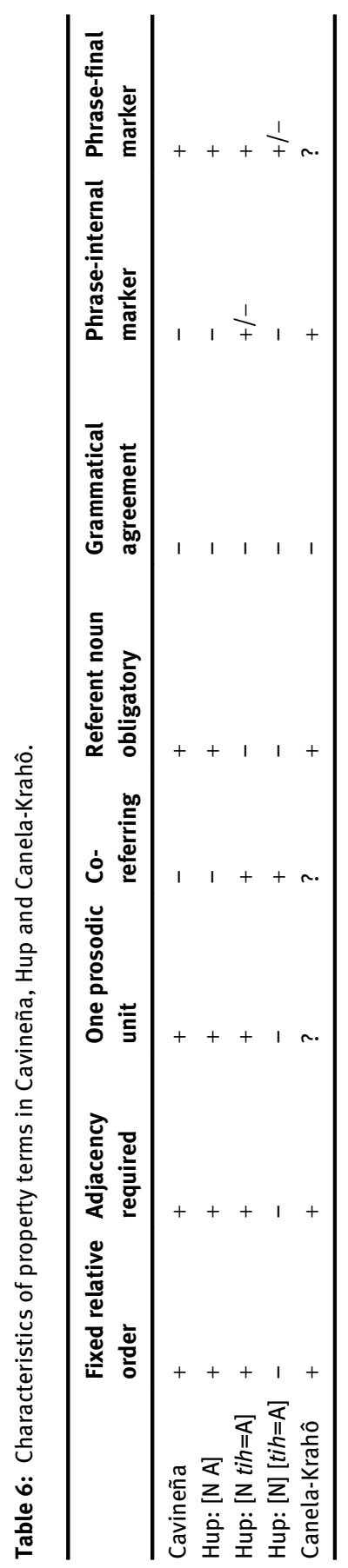


b. cho-ser

big-tooth

'big tooth'

(Danielsen 2007: 157)

Baure is a language with a rich classifier inventory. The borderline between classifiers and lexical roots is fuzzy: these notions are 'scalar', depending on the amount of lexical information that an element encodes (Admiraal and Danielsen 2014: 82). Except for a small group of highly grammaticalized classifiers, most classifiers in Baure are noted to be semantically transparent and have a less grammaticalized character, and thus could be treated on a par with lexical roots (Admiraal and Danielsen 2014). Compounding is a productive process in Baure, and, as Danielsen (2007: 134) notes "some of the classifiers have been derived from reduced noun stems, which could mean that compounding was one of the ways in which classifiers evolved in the first place”. Thus, one can analyze a property root occurring with a classifier as a derivation, but it can also be analyzed as a compound, since these do not differ formally (Admiraal and Danielsen 2014: 100). ${ }^{17}$ Thus we get constructions such as one in (20), with a classifier - $\operatorname{ar}(0)$ for liquids.

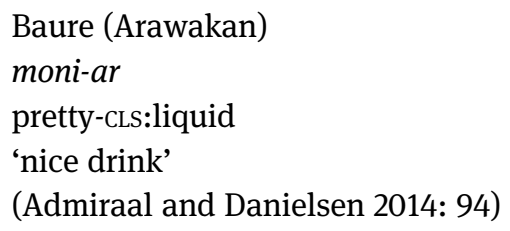

Classifiers frequently occur as 'head nouns', in the sense that the resulting complex word is referential and can occur on its own (Danielsen 2007: 169). A referent noun can also be present: Example (21) shows the property concept 'big' and the numeral 'three', both taking the classifier -wok referring to trees, and a noun ewokoe' 'tree' is also present. However, the fact that all three nominals can be used on their own (Admiraal and Danielsen 2014: 102) suggests that in this usage they can be analyzed as nominal expressions (similar to those discussed in Sections 3.1).

(21) Baure (Arawakan)

$\begin{array}{lll}\text { mbo-wok } & \text { ewokoe' } & \text { cho-wok-cha } \\ \text { three-cLs:tree } & \text { tree } & \text { big-cLs:tree-AUG }\end{array}$

'three very big trees'

(Admiraal and Danielsen 2014: 102)

17 Note that this analysis is valid for various languages spoken in Western Amazonia (e.g., Hup [Epps 2007], Harakmbut and Mojeño Trinitario [Van linden and Rose 2017; Rose and Van linden forthc.]). 
We find a parallel situation in Movima. Haude (2006: 112) argues for an existence of a separate adjective category in Movima, the members of which share many characteristics with nouns. In general, property concepts can occur as modifiers either as part of a relative clause or by forming a compound with a noun they modify semantically (Haude 2006: 115-116). Some property concepts (new, fat, hard, unripe/raw, cf. Haude [2006: 113-114]) seem always to occur as part of a compound. Similar to Baure, this means that a property term can attach to a bound lexical root (22a) or a classifier (22b). ${ }^{18}$ In either case, a property term functions as a semantic modifier, and the lexical root or a classifier as the semantic head.

$$
\begin{aligned}
& \text { Movima (unclassified) } \\
& \text { a. bijaw-kwe:ya } \\
& \text { old-woman } \\
& \text { 'old woman' } \\
& \text { (Haude 2006: 115) } \\
& \text { b. mere'-ba } \\
& \text { big-CLF:round } \\
& \text { 'big fruit' } \\
& \text { (Haude 2006: 115) }
\end{aligned}
$$

Presumably, the classifier - $b a$ for round objects has its origin in the noun $b a \sim b a: k w a$ 'fruit', which decomposes into a reduplication of the bound form $b a$ and a derivational suffix - $k w a$ (Haude 2006: 212, also fn.103). In many examples with the classifier - $b a$, a lexical noun for 'fruit' is not overtly present, but the translations indicate that the classifier is specific enough to evoke the meaning 'fruit' (e.g., Haude 2006: 481, 484, 521). Cases like this are borderline between the process of derivation (of a property root by a classifier) and the process of compounding (two lexical roots), and the analysis would presumably vary depending on individual elements involved, as their synchronic status and semantic transparency are likely to vary.

It should be mentioned for Movima that a few property concepts, among which are mere' 'big' and tochi' 'small', can also occur in simple juxtaposition with the noun. In the case of juxtaposition, there is a short pause between the two constituents and the word order is different: a property concept follows the noun (Haude 2006: 115-116). This is the same constituent order as in a relative clause construction, but without a relativizer. Interestingly, these two property concepts can also be used as adverbs to modify verbs (Haude 2006: 116). It is not clear whether different constructions with one and the same property concept entail different interpretations, for instance, in terms of permanent or temporary qualities.

18 Haude (2006) uses the term 'bound nominal element'. I refer to these elements as 'classifiers'. 
A compounding strategy can also be structurally close to noun incorporation. In the Takanan language Ese Ejja, there is a limited number of property concepts that can be used attributively. A similar situation is also reported for its sister language Cavineña, as discussed earlier. While for Cavineña, a noun and an attributively used property concept are best analyzed as two constituents forming one NP (see Guillaume 2008: 474), in Ese Ejja a noun and an attributively used property concept form a single phonological word (Vuillermet 2012: 324). However, the majority of property concepts in both languages are so-called 'predicative adjectives'. Morphologically they are marked with a semantically neutral prefix kya- when used in a citation form (Vuillermet 2012: 563). Interestingly, predicative adjectives can incorporate their semantic head nouns. Vuillermet (2012: 539, 556) observes that this strategy is productive in Ese Ejja and can be regarded as a functional approximation of attributive modification. Examples in (23) illustrate this case.

Ese Ejja (Tacanan)

a. kya-me-jewe

$$
\text { miya }
$$

APF-hand-dirty papeni

paper napa-xi!

touch-PURP

'Don't touch the book with your dirty hands!' (Lit. 'you are dirtyhanded to touch the books')

(Vuillermet 2012: 556)

b. miya

2SG.ABS

kya-chinela-beje-nee-nee

APF-flip.flop(SP)-thin-very-RED

'Your flip-flops are very thin.' (Lit. 'you are thin-flip-flopped')

(Vuillermet 2012: 563)

Compounding (property term and the head) is found at least in five of 65 sample languages, i.e., Baure, Trinitario, Ese Ejja, Movima, and Cubeo. In these languages compounding constitutes just one of the strategies (with a preference for predication in the former three languages). Except Cubeo, all other languages are spoken in the Guaporé-Mamoré region, which is shown by Crevels and van der Voort (2008) to be a linguistic area. While compounding is not mentioned among the shared features of the area, I propose that it should be explored further for areal clustering.

Interestingly, this strategy is noted by Dahl (2004: 225) to have received relatively little attention in linguistic literature. Dahl drew attention to a number of languages in which compounding with property terms is a regular strategy (viz. Lakota (Siouan), Chukchi (Chukotko-Kamchatkan), Burmese (Sino-Tibetan) and some traditional dialects of Northern Scandinavia), in some cases with both tighter and looser compounding structures (Southern Ute (Uto-Aztecan), Celtic and 
Romance languages) (see Dahl 2004: 225-236). Rießler (2016: 246-251) reports this strategy also for Adyghe and Karbardian languages in the Caucasus, Sarcee (Athapaskan) and Cayuga (Iroquoian) in North America, in Itelmen and Siberian Eskimo Yupik. Property-noun compounding is also found in Australian languages, for example, in Gunwinyguan languages from Arnhem Land (Baker and Nordlinger 2008). Furthermore, the strategy is noted to be pervasive in Sub-Saharan Africa (Creissels 2016), where this is a regular strategy for attributive modification at least within the Mande and Gur language families (Creissels 2016). SA languages remained under the radar so far regarding the compounding strategy for attributive modification.

\subsection{Attributive modification by means of classifiers}

Qualities and properties denoting shapes and physical characteristics are not necessarily rendered by lexical means but can be encoded by classifiers. It has already been noted by Payne (1990: 220) that in Western Amazon languages, which typically have few morphologically underived adjectives, classifiers can approximate the function of attributive modification. In the previous section, we saw a couple of languages in which classifiers on a property term are argued to function as the head of the phrase. However, in some cases classifiers can be argued to function as modifiers. The main piece of evidence is semantic: such classifiers add to the description of certain physical characteristics of a referent noun.

Let's take Apurinã as an example. Property concepts denoting dimension, shape and consistency can be expressed by verbs in this language. They are only found in their predicative use, never as attributive modifiers. However, Apurinã has a set of classifiers - referred to as 'classificatory nouns' in the source material that can be used either with their literal meaning, viz. semantics restricted to body elements and plant/forest elements, or with a metaphorically extended meaning (Facundes 2000: 342). Classifiers attach to any noun as part of a productive compounding strategy (i.e., involving two lexemes and carrying one primary stress) to describe its referent in terms of a shape or consistency (Facundes 2000: 342-343, 195-196). This way classifiers play the role of attributive modification along with descriptive verbs, which cover a wider range of semantic meanings (Facundes 2000: 180, 342). For example, the form ke with its source meaning 'stick of, rod of' generates a description of the referent noun as 'of a thin and generally flexible consistency' (Facundes 2000: 342). Another example is the form mata with its literal meaning 'skin' (24a). Its target meaning is 'of a flat surface'. In (24b), mata is used as part of a compound with the noun komeru 'manioc'. It results in a 
complex meaning which also contains information on the physical shape of the resulting object, in this case 'flat manioc bread'.

(24) Apurinã (Arawakan)

a. u-mata

3M-skin

'its/his skin'

(Facundes 2000: 172)

b. komeru-mata

manioc-CLF:flat.surface

'flat manioc bread'

(Facundes 2000: 172)

The occurrence of classifiers in a modifier function is also noted for Mojeño Trinitario by Rose (in prep.). Mojeño Trinitario has few morphologically underived property concepts and even those are rarely used as modifiers, with the predicative use being more common (Rose in prep.). Classifiers and property terms are complementary with regard to semantics (Rose in prep.), in the sense that the former can contribute meanings not expressed by the latter. Classifiers can express meanings mainly related to physical properties. Interestingly, as shown by Rose, a text contained 16 instances of classifiers that qualified a noun, and the same text contained 40 instances of property terms, with only 12 of them carrying out the function of modification. Just as in Apurinã, classifiers in Mojeño Trinitario do not encode a particular physical property, but they add to its interpretation.

Complementarity in terms of meaning that can be encoded through lexical items and classifiers is also found in Tariana. Tariana has no lexical means to describe a form like round, hollow, or curved. These meanings are expressed by classifiers (Aikhenvald 2003: 72). Example (25a) illustrates the attributive function of the classifier - $d a$, whereas in (25b) we see that the same classifier derives a noun with a new meaning. Example (25c) illustrates the use of the classifier-kwema for a flat object adding the semantics of being round.

(25) Tariana (Arawakan)

a. nu-kawa-ma-da

1sG-leg-CLF:side.of-CLF:round

'one round part of my leg'

(Aikhenvald 2003: 84)

b. episi-da

iron-CLF:round

'a motor'

(Aikhenvald 2003: 101) 


\section{c. kanari hanu-kwema}

mirror big-CLF:flat.round

'big round mirror'

(Aikhenvald 2003: 72)

In Cubeo (Tukanoan) the situation is similar. In Tukanoan languages, property concepts are generally encoded by stative verbs (Morse and Maxwell 1999: 123). This is also the case in Cubeo, although there is a small and closed class of underived lexemes that can be analyzed as adjectives (Morse and Maxwell 1999: 124). However, Tukanoan languages in general possess large inventories of classifiers. Example (26) shows that a combination of lexical material, a classifier, and also diminutive morphology all contribute to an overall picture of a property attributed to a referent noun. The extended translation, which is adopted from the source material, gives an impression of possible meanings.

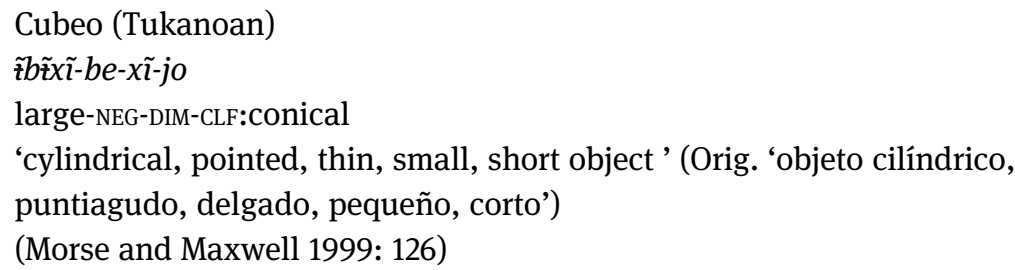

There is even a language in the sample which, among other concepts, can render color with classifier morphemes. In Mamaindê, property concepts are encoded by verbs that either need to be nominalized to occur attributively, or, most commonly, they occur as predicates taking regular verbal morphology (Eberhard 2009: 364). However, some classifiers express semantic notions typical of property concepts, and thus function as attributive noun modifiers. Mamaindê classifiers constitute a closed class of 24 elements. Relevant for our discussion is that some are semantically related to the shape of solid things (round, flat, sticklike, etc.), the physical state of non-solid entities (liquid, powder, etc.), and also to color (black, tawny) (Eberhard 2009: 330). The classifier which has a meaning 'spotted' (27a) is noted to relate to the verb root kalokalo 'spotted' (Eberhard 2009: 335, fn. 335). The fact that it is not followed by a nominalizer suggests that it is not a verb here (Eberhard 2009: 335). Eberhard further notes that the other classifiers expressing colors never occur with any verb morphology, and thus cannot be treated as verbs synchronically. Diachronically, however, the classifier -tunni 'black' (27b) is likely to originate in the verb root ton 'to be black' (David Eberhard p.c.). The capacity of grammaticalized elements - what the Mamaindê classifiers are - to express colors is typologically quite unusual. 
Mamaindê (Nambikwaran)

a. jañan-kalokalon-tu

jaguar-CLF:spotted-FNS

'spotted jaguar'

(Eberhard 2009: 335)

b. jañan-tunni-tu

jaguar-CLF:black-FNS

'black jaguar'

(Eberhard 2009: 335)

c. jañan-ei?ni-tu

jaguar-CLF:tawny-FNS

'tawny jaguar'

(Eberhard 2009: 335)

In the present sample, we find at least eight languages where classifiers (i.e., lexico-grammatical elements) can approximate the function of property concepts. ${ }^{19}$ Except for Mamaindê, semantically these are limited to the domain of dimension and physical properties.

Finally, it is of interest that a noun for 'child, offspring' can be used to express small size. In a number of SA languages, a lexeme for 'child, offspring' has taken the role of a diminutive marker. Diminutives originating in nouns for 'child, offspring' are well-attested crosslinguistically (see Jurafsky 1996 and Kuteva et al. 2019: 88-90). Kuteva et al. (2019) do not mention any SA language for this grammaticalization path. In the present sample, however, it is found in Aguaruna (Overall 2017: 173), Awa Pit (Curnow 1997: 89), Hup (Epps 2008: 353), Mojeño Trinitario (Rose 2018: 176), and Yurakaré (van Gijn 2006: 171). We can observe a similar grammaticalization from a noun meaning 'seed, kernel': it can give rise to a classifier for small objects, and/or carry out the function of a diminutive marker. This is the case in the Arawakan languages Paresí (Brandão 2014: 184), Apurinã (Facundes 2000: 253) and Mojeño Trinitario (Rose 2018: 169), ${ }^{20}$ Barbacoan Tsafiki (Dickinson 2002: 75), and also in the isolate Movima, although in Movima the use is not productive (Haude 2006: 211). Also

19 It must also be mentioned that Dahl (2004: 219-221) discusses structures which are built with 'lexical affixes', occurring in a number of languages of the Salishan, Tsimshian and Wakashan families in North America. In these languages, 'lexical affixes' have characteristics of grammatical affixes, they form relatively closed classes but have rather concrete meanings that would be associated with lexemes in most languages (Dahl 2004: 220, referring to Mithun 1997, 1998). Dahl does not discuss the use of such elements as approximants of semantic adjectives; however, the overall characteristics and the behavior of such lexical affixes parallel the one of classifiers discussed in this and the previous subsections.

20 As shown in Rose (2018, ms) Mojeño has several diminutive markers, one of which is argued to originate in a lexeme for 'child, offspring' and another one in a lexeme for 'seed'. 
note that a semantic connection between 'child, offspring' and 'seed, kernel' can be posited for some languages. This polysemy can be found in some African languages (Dogon, Susu, Baka) discussed in Kuteva et al. (2019: 89). In Paresí, we find a lexeme itsani 'son/daughter, offspring' (Brandão 2014: 205, 330), ${ }^{21}$ and there is a bound noun tse 'seed.of' (Brandão 2014: 179). Although it is not mentioned in the source material, it is not unlikely that the two lexemes are cognates. Example (28) from Apurinã illustrates the occurrences of the form - $k u$ 'seed'. (28a) shows the literal meaning of a bound noun - $k u$ 'seed / kernel'. (28b) demonstrates its grammaticalized nature: it derives a new noun with a new meaning. (28c) illustrates the form $-k u$ functioning as modifier, attributing a characteristic of being small to a referent noun.

Apurinã (Arawakan)

a. $u-k \boldsymbol{u}$

3M-seed/kernel

'its/his seed/kernel'

(Facundes 2000: 437)

b. tenu-ku

breast-CLF:seed

'nipples'

(Facundes 2000: 172)

c. amarunu-ku

boy-CLF:seed

'little boy'

(Facundes 2000: 179)

In a related language Paresí, a noun for 'seed' is formally different (viz. -tse), but it has comparable usages in the sense that (i) it derives a new meaning, similar to (28b) (Brandão 2014: 184-185), and (ii) it can express small size, in fact functioning as a diminutive marker (Brandão 2014: 187). The support for the latter is that the classifier -tse is the only classifier that can co-occur with another classifier within one word (Brandão 2014: 187). However, whether it is the classifier or the bound noun that has developed into a diminutive marker remains open.

\section{Diachronic considerations}

Let us consider constituent order tendencies in the data. SA languages are known to be predominantly verb-final at the clause level, typically with SOV order for transitive clauses and SV for intransitives (see also Dryer 2013a). If we look at the

21 Note a close formal correspondence between this lexical form and the form chicha /tsitsa 'small, endearment' reported in Rose (2018: 165) for Mojeño. 
order of a property concept as a modifier category and its semantic head, the property term following the head is more common than the opposite word order. In Krasnoukhova's (2012: 160) sample of 55 SA languages, the order [Noun-Property] in the NP was found in 50\% of the sample, whereas [Property-Noun] accounted for only $20 \% .^{22}$ The present sample, although larger and somewhat different in composition, confirms this distribution. The postnominal use of property terms as modifiers is also most common crosslinguistically: in Dryer's (2013b) world-wide sample of 1,366 languages, postnominal property terms occur in $64 \%$ of the sample (878 languages). However, as Dryer (2013b) observes, there are geographical patterns, and South America as a continent shows the postnominal position of property terms as the major type.

While hard-and-fast generalizations are difficult to draw, it is possible to note that in the present sample the order [Property-Noun] is often - but not always found with property terms that are reported to share characteristics with nouns (despite forming a separate adjective class, shown in Table 1 with 'A'). We find it, for example, in Quechuan and Aymaran languages, Leko, Mapudungun, Awa Pit, and Movima. ${ }^{23}$ Another point to note: in languages allowing both orders, the order [Property-Noun] seems to be associated with a higher degree of syntactic bondedness compared to the opposite order (see also Dahl [2004: 236]; Croft and Deligianni [2001], in Dahl [2004]).

The order [Noun-Property], dominant in South America, is seen with property terms that are verbal in nature. However, this order is also found with property terms that have mixed characteristics, and, although marginally, with nominal property terms too (e.g., Chamacoco, Warao, Pilagá).

While there have been claims in the literature (e.g., Lehmann 1973; Vennemann 1974) that the order at the clause level and the order of noun and modifying property term show some dependency, it was shown by Dryer $(1988,1992)$ that these categories do not correlate: property terms "do not precede the noun any more often in OV languages than they do in VO languages" (Dryer 1992: 133). The tendency towards postnominal use of property terms in South America raises the question whether these could, historically, constitute predicate structures. As noted earlier, some SA languages do not allow attributive use of property concepts in the first place, and many others seem to favor the predicative use. Thus, it might be the case that - at least in some languages - postnominal property terms were predicates that developed into noun modifiers. In what follows I will briefly

22 In 20\% of languages of the sample both orders were possible but under specific conditions in, and in the other 10\% property terms did not occur as modifiers (Krasnoukhova 2012: 160).

23 Although not included in the sample, the following languages provide additional support to the argument: Cholón, Mochica, Puquina and Kallawaya, all spoken in the Central Andes. 
explore one possible development using the case of Canela-Krahô (Macro-Ge) and Apurinã (Arawakan).

In Canela-Krahô property terms used predicatively have a structure similar to that of an intransitive clause. Examples (29a) and (29b) illustrate the property terms $m p \varepsilon i$ 'good' and $v \varepsilon j$ 'old' functioning as predicates; in (29c) the predicate is a

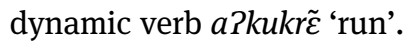

(29) Canela-Krahô (Macro-Ge)
a. rop mpej
dog good
'The dog is nice.'
(Alves 2004: 58)
b. ikre ita vej
house DEM old
'The house is old.'
(Alves 2004: 59)

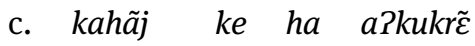
woman 3 IRR run
'The woman will run.'

(Alves 2004: 57)

Example (30) shows the property term mpci 'good' as a modifier: it can occur as such when relativized. Relative clauses are marked by the forms ita and ata, which are also demonstrative pronouns synchronically (Alves 2004: 140).

$$
\begin{aligned}
& \text { Canela-Krahô (Macro-Ge) }{ }^{24}
\end{aligned}
$$

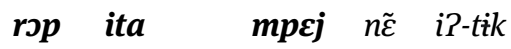

$$
\begin{aligned}
& \text { dog DEM/REL good ss 3-die } \\
& \text { 'The nice dog died.' (Lit. 'Dog this/which is nice it dies') } \\
& \text { (Alves 2004: 59) }
\end{aligned}
$$

The source material does not include information on intonation contours of clauses like (30), i.e., whether or not a property term introduced with a (demonstrative / relative) pronoun is under a unified intonation contour with the noun. Historically, the construction could have constituted separate clauses joined together by parataxis. It has been shown in Givón (2015: 637) that these can develop into syntactic structures with a relative clause. It is not unlikely that the structure of (30) was originally a sequence of clauses, starting with a free topic

24 Alves (2004: 88) analyses the element $n \tilde{\varepsilon}$ as a coordination marker for clauses with the 'same subject'; in Popjes and Popjes (1986: 147-148) it is analysed as a clause coordination marker but not nessesarily involving same subjects. 
'dog, this.one (is) good, it dies'. In fact, according to Maxwell Miranda (p.c.), who works on the Krahô variety, this can still be an interpretation synchronically. In Krenak, another Macro-Ge language, the structure in (31) is noted to be ambigous between attribution versus predication (Pessoa 2012: 216).

\author{
Krenak (Macro-Ge) \\ mĩñã $\quad$ him \\ water sweet \\ 'The water is sweet' or 'sweet water'
}

(Pessoa 2012: 216)

According to Maxwell Miranda (p.c.), the presence of a relational prefix is the only formal device that disambiguates attributively used property terms from their use as predicates. This means that the only non-ambigous construction of attributive modification would be the one involving a relational prefix, as illustrated in (32) below and also in (17-18) above.

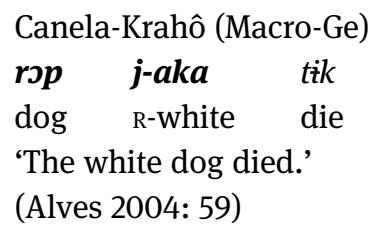

The example of these Macro-Ge languages suggests that these languages may allow some reanalysis of predicate structures into NP structures (with a head and modifying property term): either as a relative clause structure (as in 30) or as unmarked juxtaposition (as in 31). The existence of (32) may point to an emergence of mechanisms to express attribution with little ambiguity involved.

If we take a look at the Arawakan language Apurinã, we presumably see a similar scenario. Recall that most property concepts in Apurinã are encoded by verbs. Examples (33a) and (33b) show a property term 'be big' and 'be pretty' with the notional subject marked by a pronominal affix. There are some differences between the types of verbs though: intransitive verbs expressing events would carry a subject pronominal prefix (agreeing in gender and number with the notional subject); it is overtly present only if the free (pro)nominal subject is postverbal, and it is absent if the subject is preverbal (Facundes 2000: 382-383), as in (33c). Intransitive verbs expressing psychological and physical states (e.g., 'be tired', 'be hot') align with the event verbs and take subject pronominal prefixes (Facundes 2000: 279). Intransitive verbs that express qualities and properties (e.g., 'be big', 'be pretty'), however, occur with object pronominal suffixes (agreeing in gender and number with the notional subject, formally identical to object suffixes on transitive verbs, thus following a split-S pattern). There seems to 
be little evidence for any attributive use of most verbal property terms. The structure involving these lexemes that seems closest to attributive modification is exemplified in (33d). However, one can clearly identify it as containing two predicates.

(33) Apurinã (Arawakan)
a. mita-ru aiko
be.big-3м.0 house[M]
'The house is big.'
(Facundes 2000: 282)
b. suto here-ro
woman be.pretty-3F.o
'The woman is pretty.'
(Facundes 2000: 563)
c. suto
apo-pe
woman arrive-PFv
'The woman has arrived.'
(Facundes 2000: 563)
d. suto here-ro apo-pe
woman be.pretty-3F.o arrive-PFV
'The woman who's pretty has arrived.'
(Facundes 2000: 563)

Note that outside South America, a similar development, with the [Noun-Property] construction deriving from the [Subject Verb] construction "without any change in the order of constituents, and often without any change at all in the form of the constituents as well” has been discussed for Yuman languages of North America by Langdon (1977: 258-261). As Langdon (1977: 261) puts it, "the placement of the adjective after its head noun is nothing more than the retention in surface structure of the Subject + Verb order demanded by SOV languages".

The typology of attributive constructions that we discussed in Section 3 can be seen as a continuum of syntactic complexity. In Figure 1, I give a scheme of how the observed constructions for predicative and attributive use of property terms can be related. Naturally, historical processes are considerably more complex than the scheme suggests, with multiple steps in between.

Since I do not have enough relevant data to substantiate the suggested connections, I leave this question open. However, separate segments of the diachronies have been suggested in the crosslinguistic literature. For one thing, nominal expressions can develop into syntactically hierarchical integral NPs. For 


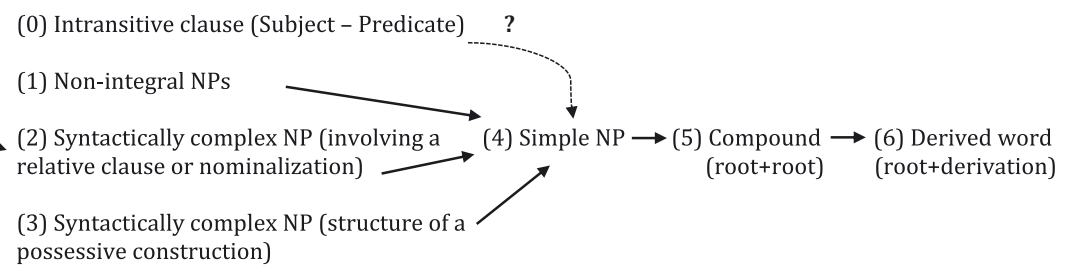

Figure 1: Suggested connections between different types of constructions.

example, a gradual development of an internal slot for attributive modifiers and thus gradual integration of property terms into an NP has been shown for Dutch by Van de Velde (2009a, 2009b). It has also been argued by Langacker (1977: 107) that languages show a general drive towards "constructional simplicity", with a tendency of marked categories to be replaced by relatively unmarked ones. Thus, relative clauses as modifiers can develop towards a simple NP via a stage in which a relative marker becomes optional. Compounding and derivation have a fluid borderline (Lieber and Štekauer 2009), exactly for the reason that these structures can represent different stages in one diachronic development.

\section{Concluding remarks}

This study focused on attributive modification in SA indigenous languages. A typology of constructions that are used for the function of modification was shown to constitute a continuum: with nominal expressions (i.e., non-integral NPs) on the one end, and a morphologically tight structure, ambiguous between compounding and derivation, on the other end. A language would typically make use of more than one construction, and there can be variation between individual lexemes even within one semantic class.

A simple integral NP for attributive modification is possible in less than half of the sample (28 out of 65 languages, in 12 out of 28 this is the only available strategy). Thus, simple NPs is not the dominant or typical strategy for attributive modification in SA data, and languages would reply on other strategies. A relative clause or nominalization construction is one of the options. A few languages (the Cariban languages, Bora) stand out - also at the world level - by relying (for attributive modification) exclusively on nominal expressions, i.e., constructions with a limited syntactic unithood. Those SA languages that have multifunctional classifiers would typically have attributive constructions that range from a syntactically loose to a tight construction, depending on the property lexeme and a 
type of classifier. Most of such languages are confined geographically to the Northwest and Southwest Amazon region. In some of the languages with classifiers, the latter can participate in attributive modification as approximations to adjectives of dimension and physical properties. Furthermore, it was shown that some SA languages use compounding as a strategy for attributive modification. While this phenomenon has been reported for languages from different parts of the world, the SA languages remained under the radar. Finally, attributive constructions akin to a possession construction, typical for the Oceanic languages (Rießler 2016: 38), are also encountered in SA although only marginally.

Finally, in this study I tentatively suggested that some segments of the proposed continuum of attributive modification are diachronically related. Furthermore, while attributive modification is possible in many sample languages, about a quarter of the languages show a strong preference towards the predicative use of property terms, with the attributive use being avoided (or, in some languages, not even available). In this light I put forward a conjecture that one of the possible developments could have involved a syntactic reanalysis of [Subject Predicate] intransitive clauses into an NP structure with a head noun and a postnominal property term.

\section{Abbreviations}

$\begin{array}{ll}1 & \text { 1st person } \\ 2 & \text { 2nd person } \\ 3 & \text { 3rd person } \\ \text { A } & \text { subject of transitive verb } \\ \text { ABS } & \text { bsolutive } \\ \text { ADJ } & \text { adjective } \\ \text { AFF } & \text { affirmative } \\ \text { AGT } & \text { agent } \\ \text { AN } & \text { animate } \\ \text { APF } & \text { adjective prefix } \\ \text { ASR } & \text { assertive } \\ \text { AUG } & \text { augmentative } \\ \text { C.NMLZ } & \text { circumstance nominalizer } \\ \text { CLF } & \text { classifier } \\ \text { COP } & \text { copula } \\ \text { DECL } & \text { declarative } \\ \text { DEM } & \text { demonstrative } \\ \text { DIM } & \text { diminutive } \\ \text { DYNM } & \text { dynamic } \\ \text { ERG } & \text { ergative } \\ \text { F } & \text { feminine } \\ \text { FM } & \text { formative }\end{array}$




\begin{tabular}{|c|c|}
\hline FNS & final nominal suffix \\
\hline FOC & focus \\
\hline FS & female speaker \\
\hline INFR & inferential evidential \\
\hline IPFV & imperfective \\
\hline IRR & irrealis \\
\hline HRSY & hearsay \\
\hline LOC & locative \\
\hline M & masculine \\
\hline $\mathrm{N}$ & neuter \\
\hline $\mathrm{N}$ & noun \\
\hline NEG & negation \\
\hline NEG & negative \\
\hline NMLZ & nominalization \\
\hline NPF & noun prefix \\
\hline 0 & object pronominal marker \\
\hline OBJ & object \\
\hline OBL & oblique \\
\hline PFV & perfective \\
\hline PL & plural \\
\hline PRO & pronoun \\
\hline PROP & proper \\
\hline PRS & present \\
\hline PST & past \\
\hline PT & loan word from Portuguese \\
\hline PURP & purpose \\
\hline PURP.MOT & purpose of motion \\
\hline $\mathrm{R}$ & relational \\
\hline RED & reduplication \\
\hline REL & relative \\
\hline REP & reportative evidential \\
\hline $\mathrm{RP} / \mathrm{P}$ & realis past/present \\
\hline s & subject of intransitive verb \\
\hline SG & singular \\
\hline SP & Spanish loan \\
\hline SS & same subject \\
\hline SUB & subordinate \\
\hline TEL & telic \\
\hline
\end{tabular}

Acknowledgments: Many thanks are due to two anonymous reviewers and the editor for constructive and very helpful comments and suggestions. I would also like to express my thanks to Ann Kelly for all the help with editorial matters. My gratitude goes also to Dana Louagie, Uta Reinöhl and Johan van der Auwera for all invaluable feedback on earlier versions of the manuscript. A big thank-you is due to the following colleagues for additional information on the language of their expertise and for providing me with feedback which was most helpful: 
David Eberhard (Mamaindê), Françoise Rose (Mojeño Trinitario and Tupian), Hein van der Voort (Kwaza), Joshua Birchall (Wari'), Maxwell Miranda (Ge), Patience Epps (Hup) and Rosa Vallejos (Kukama-Kukamiria).

\section{Appendix 1: Attributive modification in South American indigenous languages}

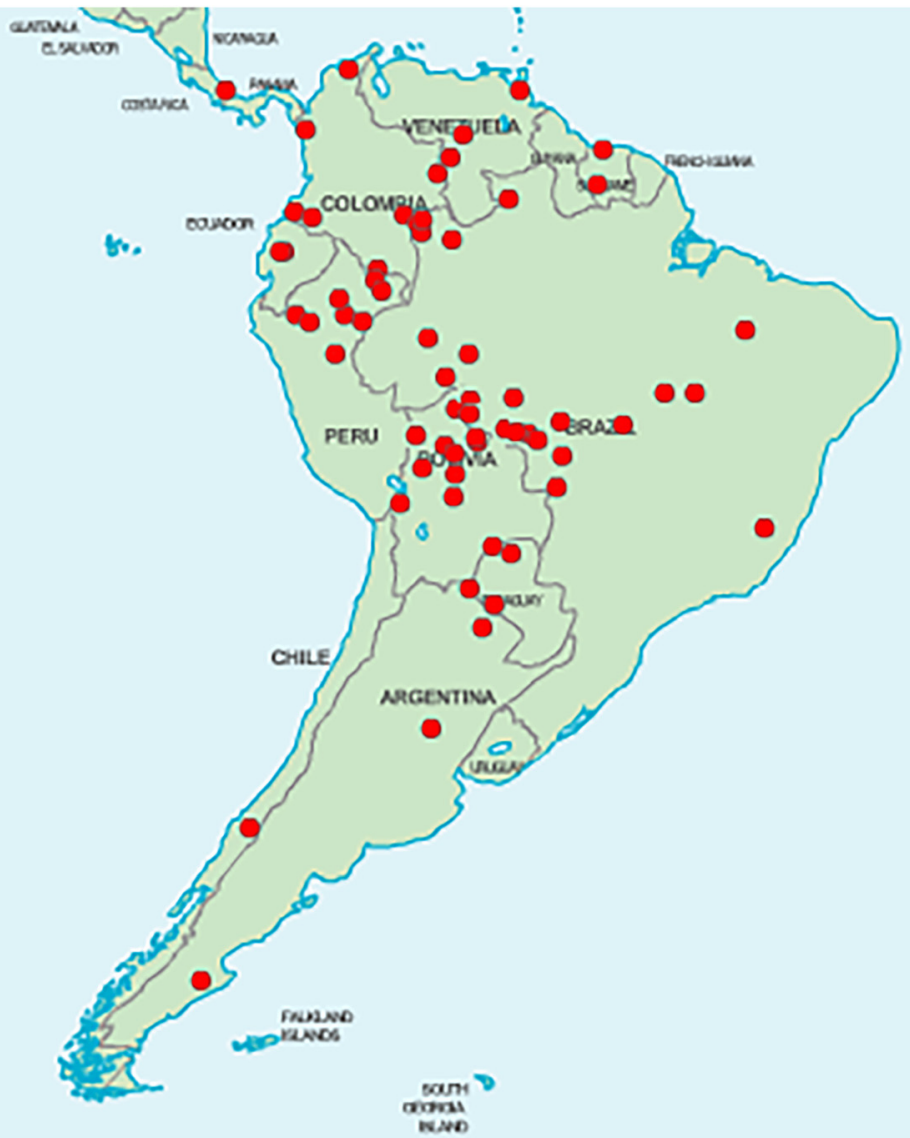

Map 1: Geographical distribution of the sample languages. 


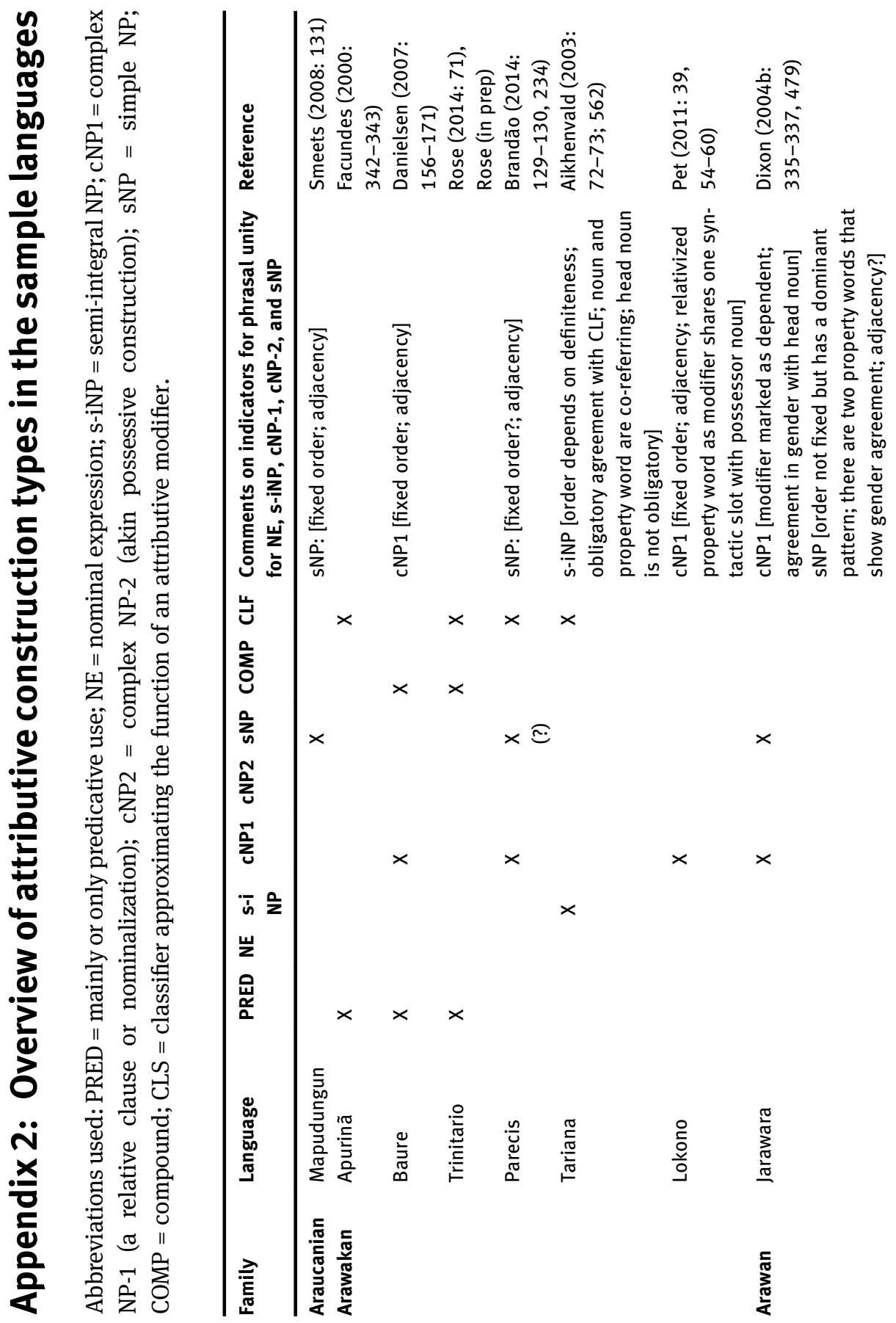




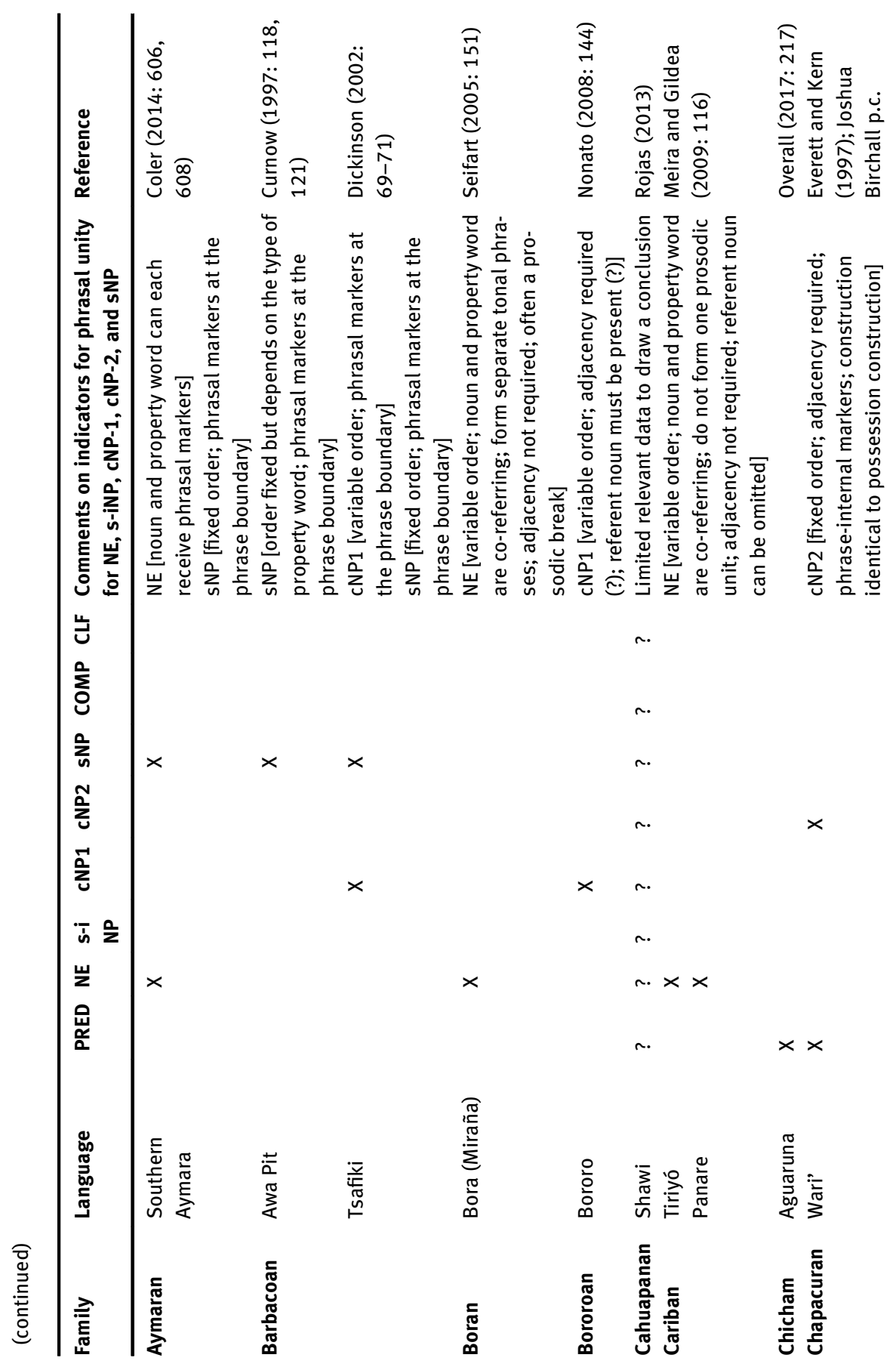




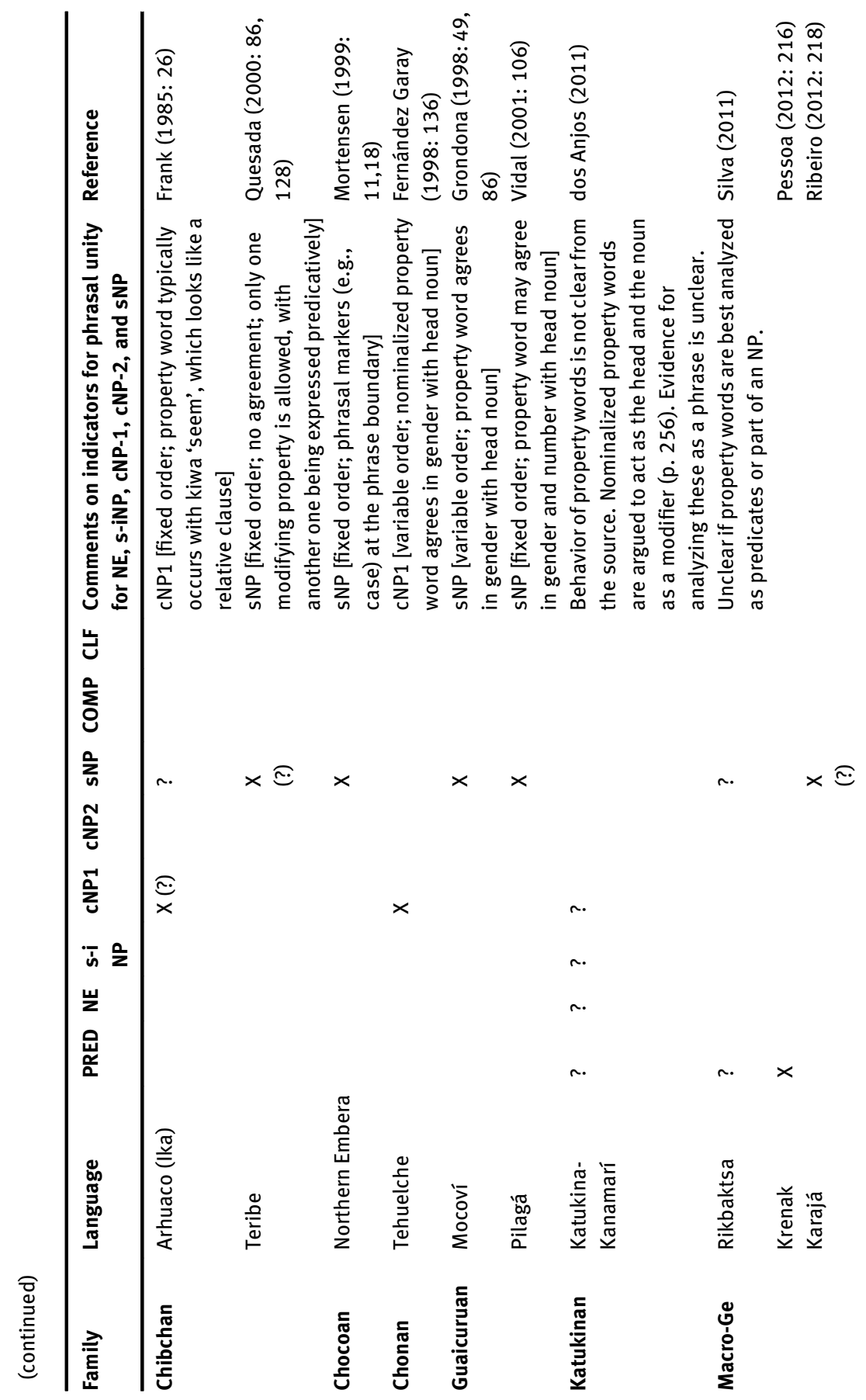




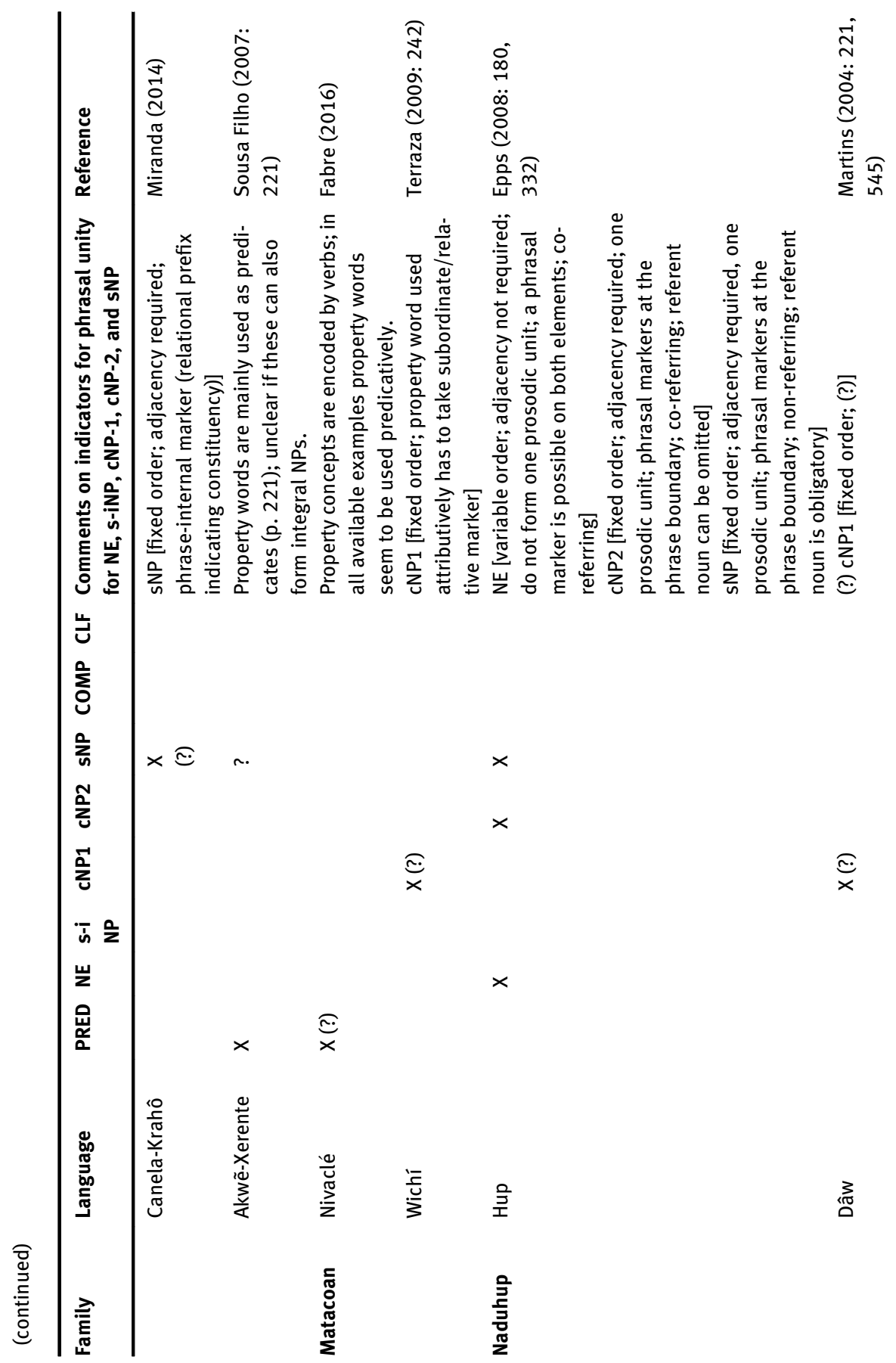




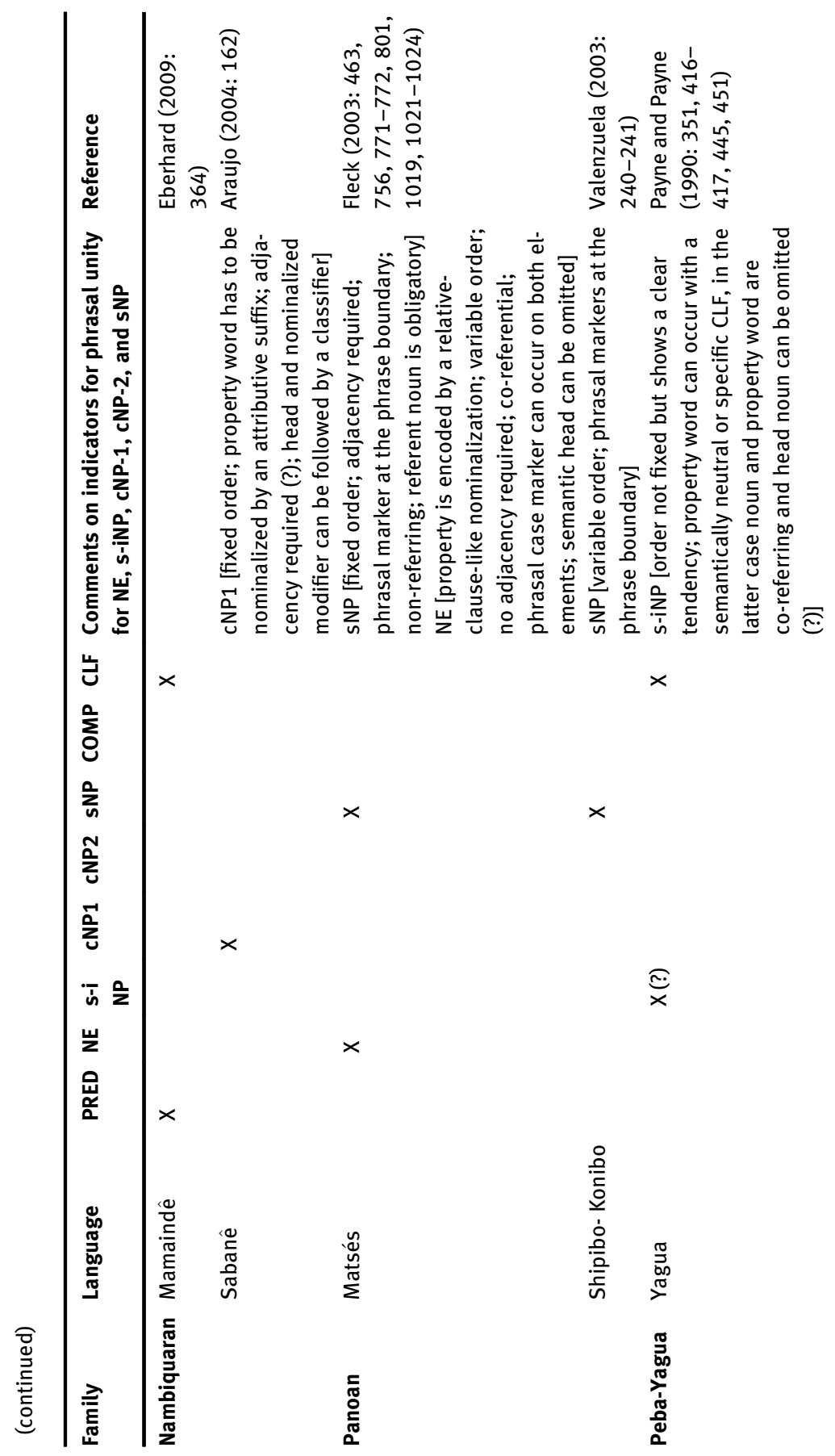




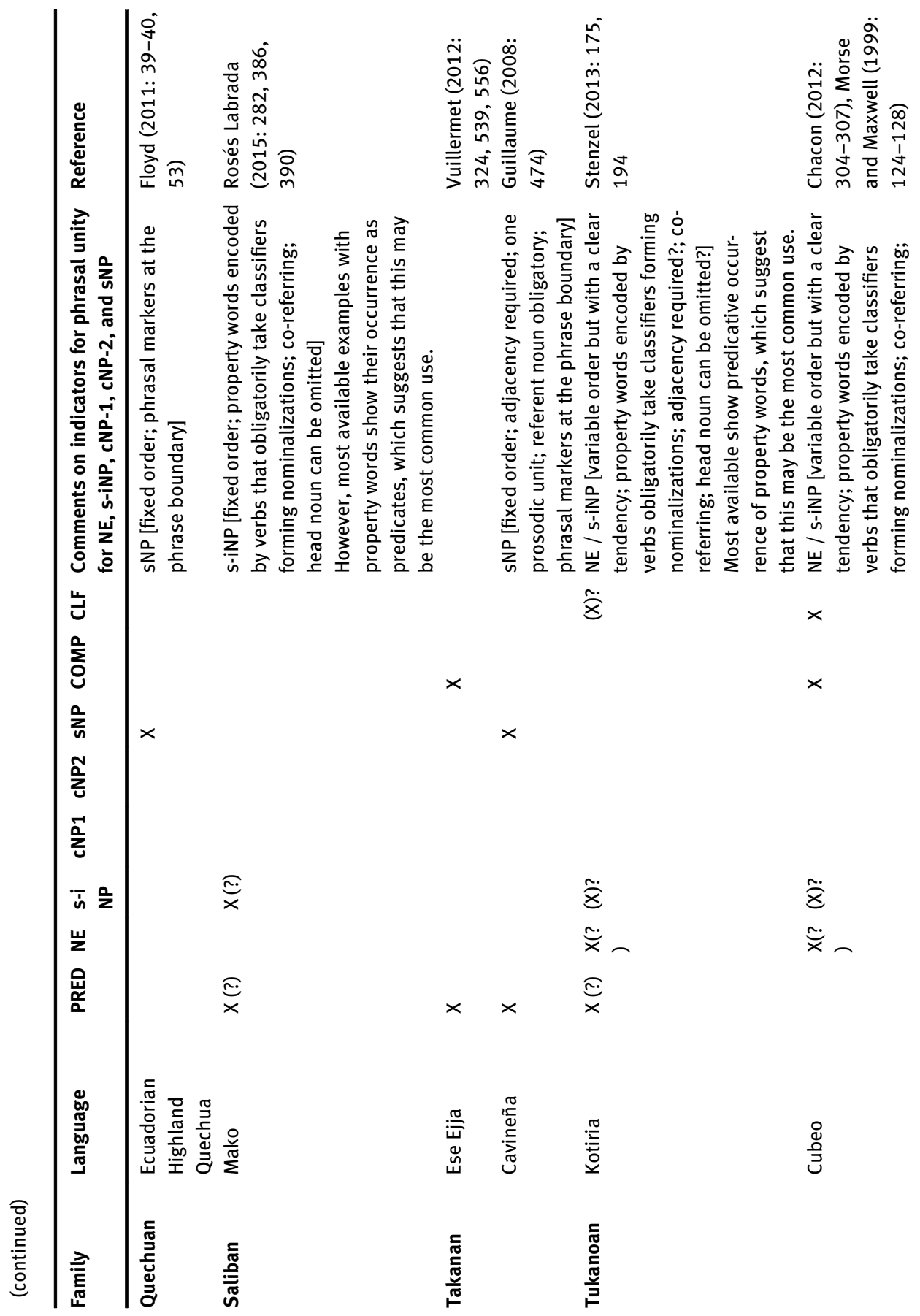




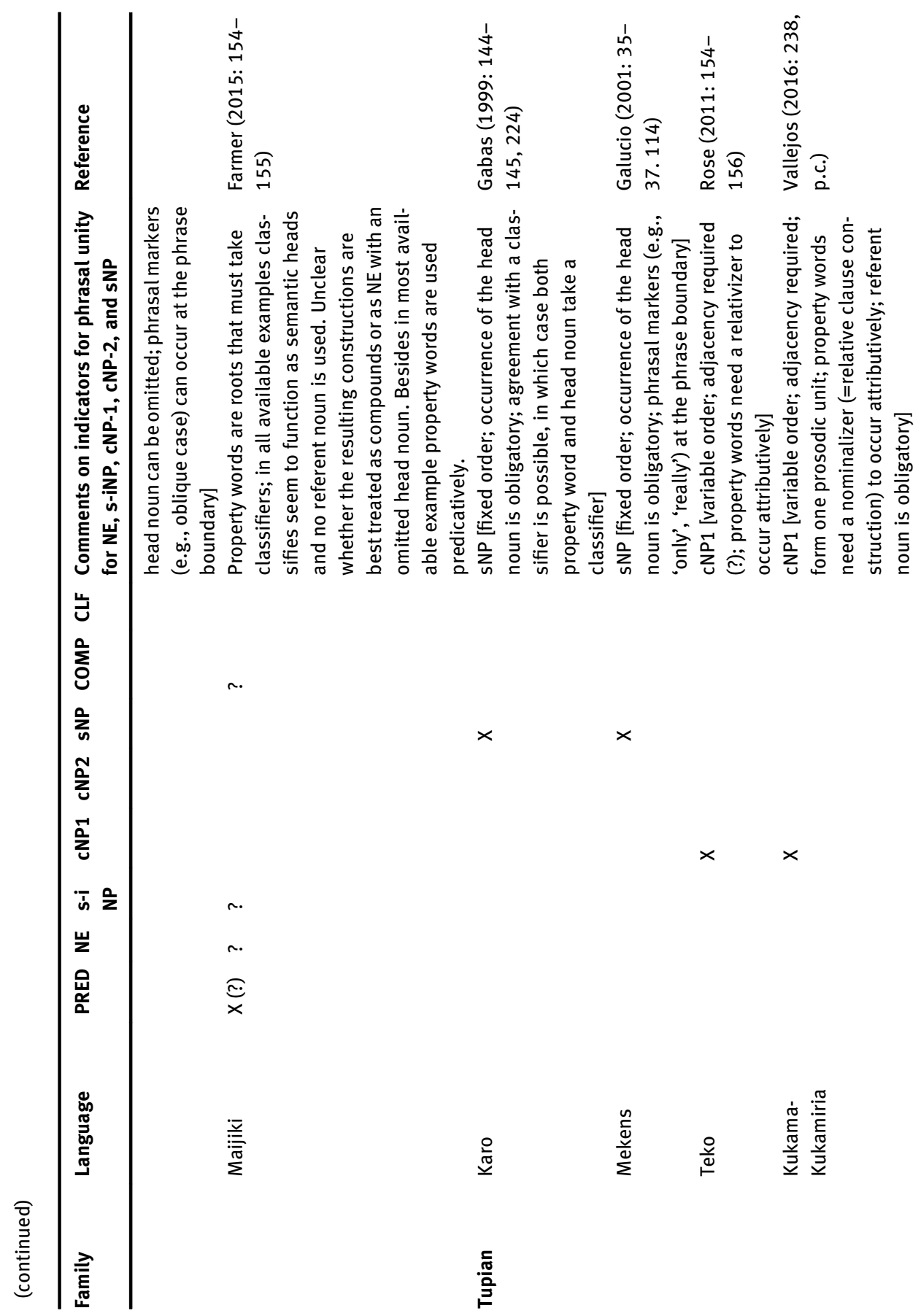




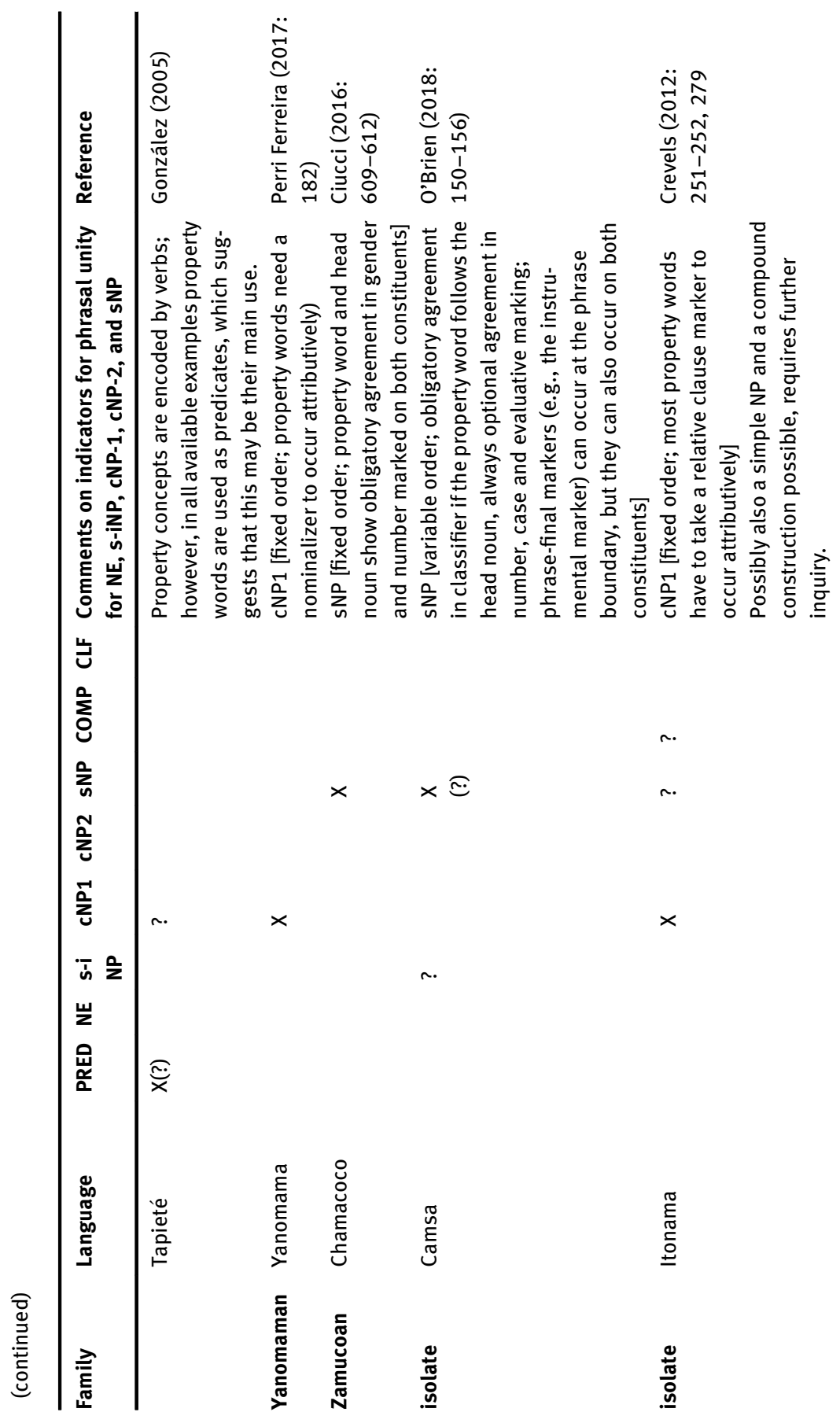




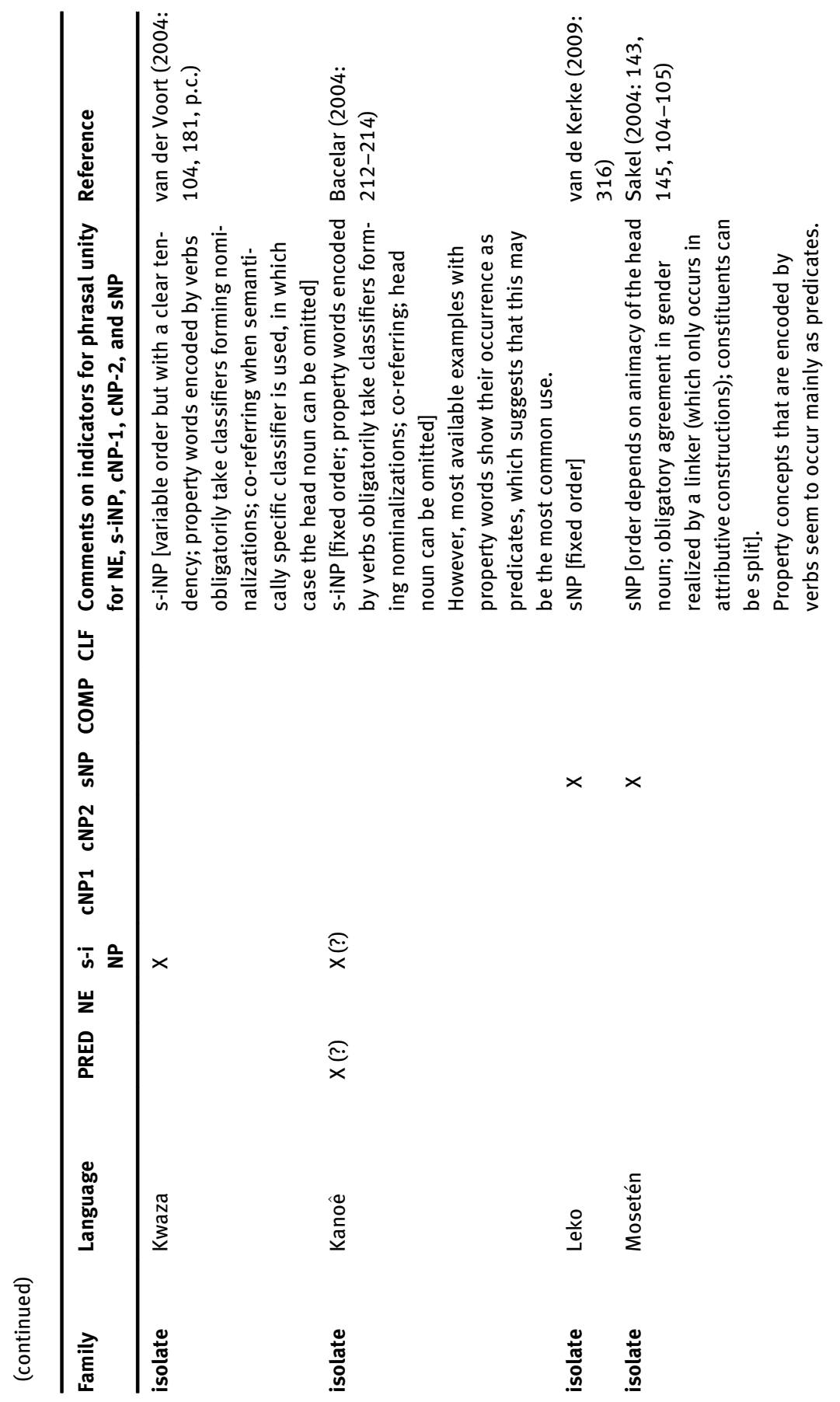




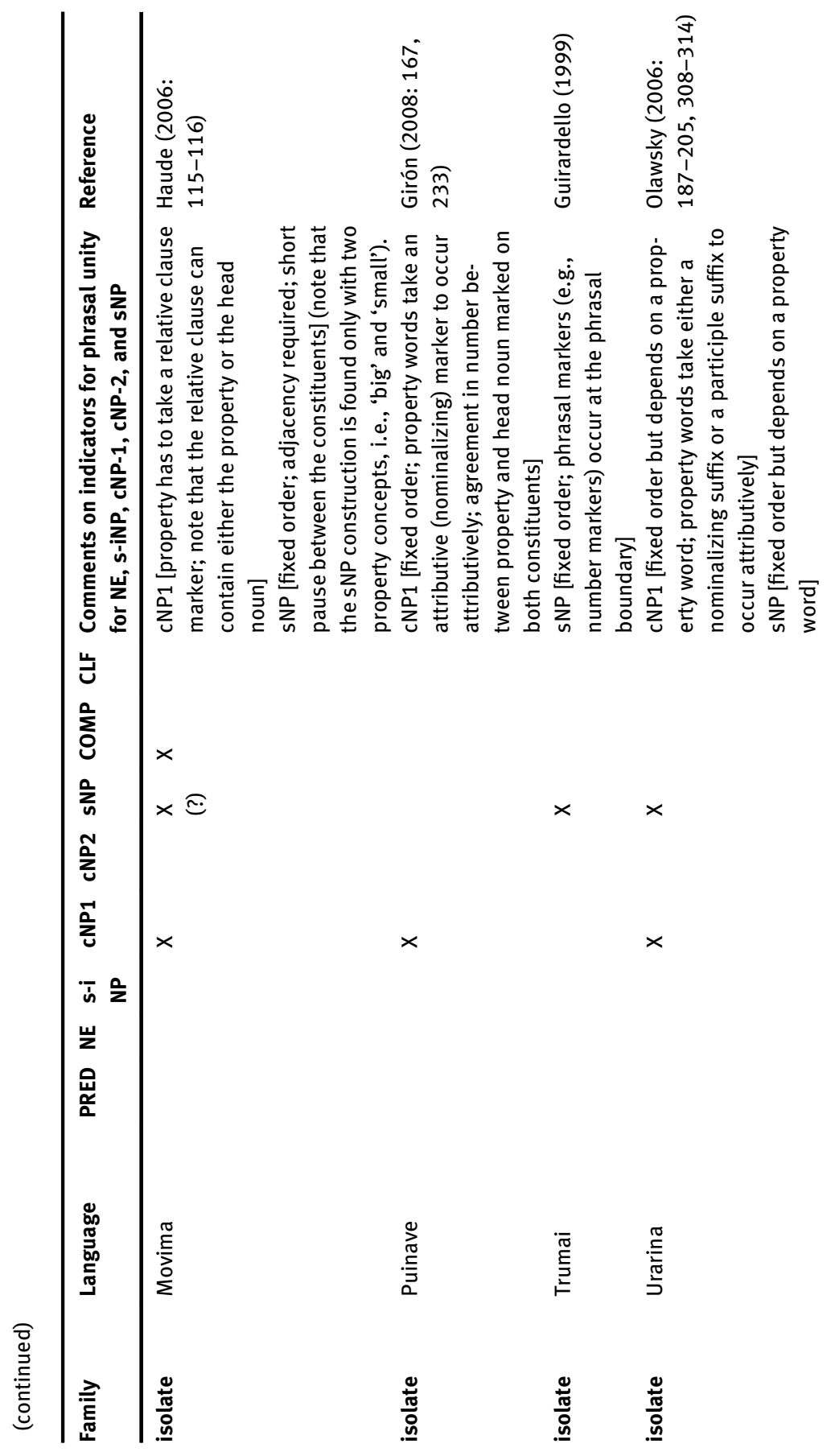




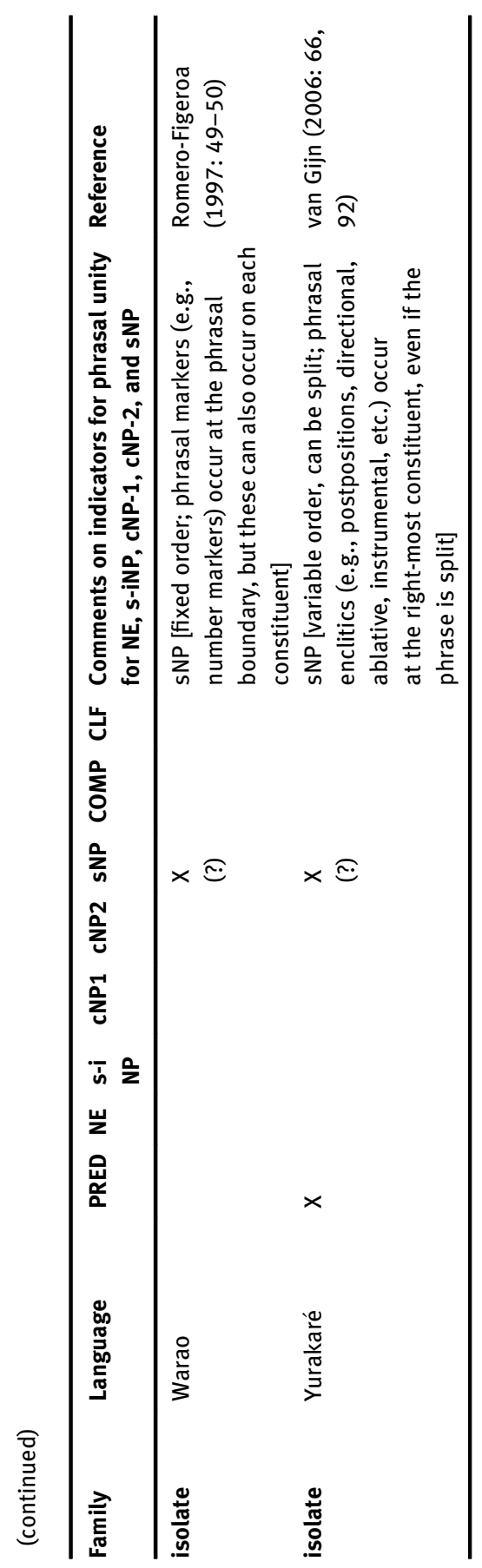




\section{References}

Abbott, Miriam. 1991. Macushi. In Desmond C. Derbyshire \& Geoffrey K. Pullum (eds.), Handbook of Amazonian languages, 23-160. Berlin \& New York: Mouton de Gruyter.

Admiraal, Femmy \& Swintha Danielsen. 2014. Productive compounding in Baure (Arawakan). In Swintha Danielsen, Katja Hannß \& Fernando Zúñiga (eds.), Word formation in South American languages, 79-112. (Studies in Language Companion Series, 163). Amsterdam/ Philadelphia: John Benjamins Publishing Company.

Aikhenvald, Alexandra. 1996. Areal diffusion in North-West Amazonia: The case of Tariana. Anthropological Linguistics 38. 73-116.

Aikhenvald, Alexandra. 2000. Classifiers. A typology of noun categorization devices. Oxford: Oxford University Press.

Aikhenvald, Aleksandra. 2003. A grammar of Tariana. Cambridge: Cambridge University Press. Alves, Flávia de Castro. 2004. O Timbira Falado Pelos Canela Apãniekrá: Uma Contribução aos Estudos da Morfossintaxe de uma Língua Jê. [Timbira as spoken by the Canela Apãniekrá: A contribution to the study of morphosyntax of a Gê language]. Campinas: Universidade Estadual de Campinas dissertation.

Araujo, Gabriel Antunes de. 2004. A grammar of Sabanê: A Nambikwaran language. [Vrije Universiteit Amsterdam] (LOT Dissertation Series 94). Utrecht: LOT Publications.

Bacelar, Laércio Nora. 2004. Gramática da língua Kanoê. [A grammar of the Kanoê language]. Nijmegen: Radboud Universiteit Nijmegen dissertation.

Bacelar, Laércio Nora \& Augusto R. Silva Jr. 2003. Tipologia da negação em Kanoê. [Typology of negation in Kanoê]. Signótica: Revista do Mestrado am Letras e Linguística 15(2). 237-247.

Baker, Brett \& Rachel Nordlinger. 2008. Noun-adjective compounds in Gunwinyguan languages. In Butt Miriam \& Holloway King Tracy (eds.), Proceedings of the LFG08 Conference, 109-128. Stanford, CA: CSLI Publications.

Bauer, Laurie. 2009. Typology of compounds. In Lieber Rochelle \& Štekauer Pavol (eds.), The Oxford handbook of compounding, 343-356. Oxford: University Press.

Beck, David. 2002. The typology of parts of speech systems: The markedness of adjectives. New York \& London: Routledge.

Brandão, Ana Paula Barros. 2014. A reference grammar of Paresi-Haliti (Arawak). Austin, TX: University of Texas at Austin dissertation.

Campbell, Lyle \& Verónica Grondona. 2012. Languages of the Chaco and Southern Cone. In Lyle Campbell \& Verónica Grondona (eds.), The indigenous languages of South America: A comprehensive guide, 625-667. Berlin \& Boston: De Gruyter Mouton.

Chacon, Thiago Costa. 2012. The phonology and morphology of Kubeo: The documentation, theory, and description of an Amazonian language. Honolulu: University of Hawai'i at Mānoa dissertation.

Ciucci, Luca. 2016. Inflectional morphology in the Zamucoan languages. Asunción: CEADUC.

Ciucci, Luca. 2019. The adjective class in Chamacoco. Paper presented at the Language and Culture Research Centre, James Cook University, Cairns. November 20, 2019.

Coler, Matt. 2014. A grammar of Muylaq' Aymara: Aymara as spoken in Southern Peru. Leiden: Brill.

Creissels, Denis. 2016. Noun + adjective compounding and quasi-compounding in the languages of Sub-Saharan Africa. Paper presented at the Syntax of the World's Languages 7, Mexico, August 17-19. 
Crevels, Mily. 2012. Itonama. In Crevels Mily \& Muysken Pieter (eds.), Ambito Andino, 233-294. La Paz: Plural Editores.

Crevels, Mily \& Hein van der Voort. 2008. The Guaporé-Mamoré region as a linguistic area. In Pieter Muysken (ed.), From linguistic areas to areal linguistics, 151-179. Amsterdam \& Philadelphia: John Benjamins.

Croft, William. 1991. Syntactic categories and grammatical relations: The cognitive organization of information. Chicago, IL: University of Chicago Press.

Croft, William. 2003. Typology and universals, 2nd edn. (Cambridge Textbooks in Linguistics). Cambridge: Cambridge University Press.

Croft, William \& Efrosini Deligianni. 2001. Asymmetries in NP word order. In Paper presented at the International Symposium on Deictic Systems and Quantification in Languages Spoken in Europe and Northern and Central Asia, Udmurt State, Izhevsk, Russia, May 2001.

Crowell, Thomas H. 1979. A grammar of Bororo. Ithaca, NY: Cornell University dissertation.

Curnow, Timothy. 1997. A grammar of Awa Pit (Cuaiquer): An indigenous language of south-western Colombia. Canberra: Australian National University dissertation.

Dahl, Östen. 2004. The growth and maintenance of linguistic complexity (Studies in language companion series 71). Amsterdam \& Philadelphia: John Benjamins.

Danielsen, Swintha. 2007. Baure: An Arawak language of Bolivia. (Indigenous Languages of Latin America 6). Leiden: Research School of Asian, African and Amerindian Studies (CNWS), Universiteit Leiden.

Derbyshire, Desmond \& Doris Payne. 1990. Noun classification systems of Amazonian languages. In Doris Payne (ed.), Amazonian linguistics: Studies in lowland South American languages, 243-271. Austin, TX: University of Texas Press.

Dickinson, Connie. 2002. Complex predicates in Tsafiki. Eugene, OR: University of Oregon dissertation.

Dixon, R.M.W. 1977. Where have all the adjectives gone? Studies in Language 1. 19-80.

Dixon, R.M.W. 1982. Where have all the adjectives gone? And other essays in semantics and syntax. Berlin \& New York: Mouton de Gruyter.

Dixon, R.M.W. 2004a. Adjective classes in typological perspective. In R.M.W. Dixon \& Alexandra Aikhenvald (eds.), Adjective classes: A cross-linguistic typology, 1-49. Oxford: Oxford University Press.

Dixon, R. M. W. 2004b. The Jarawara language of southern Amazonia. Oxford: Oxford University Press.

Dixon, R.M.W. 2010. Basic linguistic theory, vol. 2: Grammatical topics. Oxford: Oxford University Press.

dos Anjos, Zoraide. 2011. Fonologia e gramática Katukina-Kanamari. [Phonology and grammar of Katukina-Kanamari]. Amsterdam: Vrije Universiteit Amsterdam dissertation.

Dryer, Matthew. 1988. Object-verb order and adjective-noun order: Dispelling a myth. Lingua 74. 185-217.

Dryer, Matthew. 1992. The Greenbergian word order correlations. Language 68. 81-138.

Dryer, Matthew. 2013a. Order of subject, object and verb. In Matthew Dryer \& Martin Haspelmath (eds.), The world atlas of language structures online. Leipzig: Max Planck Institute for Evolutionary Anthropology.

Dryer, Matthew. 2013b. Order of Adjective and Noun. In Matthew S. Dryer \& Martin Haspelmath (eds.), The world atlas of language structures online. Leipzig: Max Planck Institute for Evolutionary Anthropology. 
Eberhard, David M. 2009. Mamaindê grammar: A northern Nambikwara language and its cultural context. Amsterdam: Vrije Universiteit Amsterdam dissertation.

Epps, Patience. 2007. Birth of a noun classification system: The case of Hup. In Leo Wetzels (ed.), Language endangerment and endangered languages: Linguistic and anthropological studies with special emphasis on the languages and cultures of the Andean-Amazonian border area (Indigenous Languages of Latin America series), 107-128. Leiden: Leiden University, Research School of Asian, African, and Amerindian Studies (CNWS).

Epps, Patience. 2008. A grammar of Hup. (Mouton Grammar Library 43). Berlin \& New York: Mouton de Gruyter.

Everett, Daniel L. \& Barbara Kern. 1997. Wari': The Pacaas Novos language of Western Brazil. (Descriptive Grammars Series). London \& New York: Routledge.

Fabre, Alain. 2016. Estudio gramatical de la lengua Nivacle. (Familia Mataguayo, Chaco Paraguayo) [Grammar study of the Nivacle language. (Mataguayo Family, Paraguayan Chaco)]. (LINCOM Studies in Native American Linguistics 78). Munich: Lincom.

Facundes, Sidney da Silva. 2000. The Language of the Apurinã people of Brazil (Maipure/Arawak). Buffalo, NY: State University of New York at Buffalo dissertation.

Farmer, Stephanie J. 2015. Establishing reference in Máíhīkì. Berkeley, CA: University of California at Berkeley dissertation.

Fleck, David W. 2003. A grammar of Matses. Houston, TX: Rice University dissertation.

Floyd, Simeon. 2011. Re-discovering the Quechua adjective. Linguistic Typology 15. 25-63.

Foley, William. 1980. Toward a universal typology of the noun phrase. Studies in Language 4. 171-199.

Frank, Paul Stephen. 1985. A grammar of Ika. Philadelphia, PA: University of Pennsylvania dissertation.

Fernández Garay, Ana. 1998. El tehuelche: una lengua en vías de extinción. [Tehuelche: A language on the way to extinction] (Estudios Filológicos 15). Anejos de Estudios Filológicos. Valdivia: Facultad de Filosofía y Humanidades, Universidad Austral de Chile.

Gabas, Nilson Jr. 1999. A grammar of Karo, Tupí (Brazil). Santa Barbara, CA: University of California at Santa Barbara dissertation.

Galucio, Ana Vilacy. 2001. The morphosyntax of Mekens (Tupi). Chicago, IL: University of Chicago dissertation.

van Gijn, Erik. 2006. A grammar of Yurakaré. Nijmegen: Radboud Universiteit Nijmegen dissertation.

van Gijn, Rik. 2014. Subordination strategies in South America: Nominalization. In Loretta O'Connor \& Pieter Muysken (eds.), The native languages of South America: Origins, development, typology, 274-296. Cambridge: Cambridge University Press.

Gil, David. 2013. Genitives, adjectives and relative clauses. In Matthew S. Dryer \& Martin Haspelmath (eds.), The world atlas of language structures online. Leipzig: Max Planck Institute for Evolutionary Anthropology.

Gildea, Spike. 1998. On reconstructing grammar: Comparative Cariban morphosyntax. Oxford: Oxford University Press.

Givón, Talmy. 1995. Functionalism and grammar. Amsterdam \& Philadelphia: John Benjamins.

Givón, Talmy. 2015. The diachrony of grammar, vol. 2. Amsterdam \& Philadelphia: John Benjamins.

González, Hebe A. 2005. A grammar of Tapiete (Tupi-Guarani). Pittsburgh, PA: University of Pittsburgh dissertation. 
Grinevald, Colette. 2000. A morphosyntactic typology of classifiers. In Senft Gunter (ed.), Systems of nominal classification, 50-92. Cambridge: Cambridge University Press.

Grinevald, Colette \& Frank Seifart. 2004. Noun classes in African and Amazonian languages: Towards a comparison. Linguistic Typology 8. 243-285.

Grondona, Verónica M. 1998. A grammar of Mocovi. Pittsburgh, PA: University of Pittsburgh dissertation.

Guillaume, Antoine. 2008. A grammar of Cavineña. (Mouton Grammar Library 44). Berlin \& New York: Mouton de Gruyter.

Guirardello, Raquel. 1999. A reference grammar of Trumai. Houston, TX: Rice University dissertation.

Hammarström, Harald, Robert Forkel \& Martin Haspelmath \& Sebastian Bank. 2020. Glottolog 4.3. Jena: Max Planck Institute for the Science of Human History.

Hannß, Katja. 2008. Uchumataqu: The lost language of the Urus of Bolivia: A grammatical description of the language as documented between 1894 and 1952 (Indigenous Languages of Latin America 7). Leiden: Research School of Asian, African and Amerindian Studies (CNWS), Universiteit Leiden.

Haspelmath, Martin. 2012. How to compare major word-classes across the world's languages. UCLA Working Papers in Linguistics 17(16). 109-130.

Haude, Katharina. 2006. A grammar of Movima. Nijmegen: Radboud Universiteit dissertation.

Hengeveld, Kees. 1992. Non-verbal predication. (Functional Grammar Series 15). Berlin \& New York: Mouton de Gruyter.

Heringa, Herman. 2011. Appositional constructions. [University of Groningen] (LOT dissertation series 294). Utrecht: LOT Publications.

Girón Higuita, Jesús Mario. 2008. Una gramatica del Wansöjöt (Puinave). [A grammar of Wansöjöt (Puinave)]. [University of Amsterdam] (LOT Dissertation Series 185). Utrecht: LOT Publications.

Himmelmann, Nikolaus. 1997. Deiktikon, Artikel, Nominalphrase: Zur Emergenz syntaktischer Struktur. Tübingen: Niemeyer.

Jurafsky, Daniel. 1996. Universal tendencies in the semantics of the diminutive. Language 72(3). 533-578.

van de Kerke, Simon. 2009. El Leko. In Crevels Mily \& Muysken Pieter (eds.), Ambito Andino, 287-332. La Paz: Plural Editores.

Koptjevskaja Tamm, Maria \& Matti Miestamo. 2015. Antonyms and derivational negation: A pilot study of cross-linguistic variation. In Paper presented at the 11th Conference of the Association for Linguistic Typology, August 1-3. Albuquerque, USA: University of New Mexico.

Krasnoukhova, Olga. 2012. The noun phrase in the languages of South America [Radboud Universiteit Nijmegen]. (LOT Dissertation Series 301). Utrecht: LOT Publications.

Kuteva, Tania, Bernd Heine, Bo Hong, Haiping Long, Heiko Narrog \& Seongha Rhee. 2019. World lexicon of grammaticalization, 2nd edn. Cambridge: Cambridge University Press.

Langacker, Ronald W. 1977. Syntactic reanalysis. In Charles N. Li (ed.), Mechanisms of syntactic change, 57-139. Austin, TX: University of Texas Press.

Langdon, Margaret. 1977. Syntactic change and SOV structure: The Yuman case. In Charles N. Li (ed.), Mechanisms of syntactic change, 255-290. Austin, TX: University of Texas Press.

Lehmann, Winfred. 1973. A structural principle of language and its implications. Language 49. 47-66. 
Lieber, Rochelle \& Pavol Štekauer. 2009. Introduction: Status and definition of compounding. In Rochelle Lieber \& Pavol Štekauer (eds.), The Oxford handbook of compounding, 3-18. Oxford: University Press.

Louagie, Dana \& Jean-Christophe Verstraete. 2016. Noun phrase constituency in Australian languages: A typological study. Linguistic Typology 20. 25-80.

Louagie, Dana \& Uta Reinöhl. This issue. Typologizing nominal expressions: the noun phrase and beyond. Martins, Silvana Andrade. 2004. Fonologia e gramática Dâw. [Phonology and grammar of Dâw]. [Vrije Universiteit Amsterdam] (LOT Dissertation Series 98). Utrecht: LOT Publications.

Matthews, Peter H. 1981. Syntax. Cambridge: Cambridge University Press.

Meira, Sérgio. 1999. A grammar of Tiriyó. Houston, TX: Rice University Ph.D. dissertation. Meira, Sérgio. 2000. A reconstruction of Proto-Taranoan: Phonology and morphology. Munich: LINCOM Europa.

Meira, Sérgio \& Sebastian Drude. 2013. Sobre a origem histórica dos “prefixos relacionais” das línguas Tupí-Guaraní. [On the historical origin of the "relational prefixes" in the Tupí-Guaraní languages]. Cadernos de Etnolingüística 5(1). 1-30.

Meira, Sérgio \& Spike Gildea. 2009. Property concepts in the Cariban family: Adjectives, adverbs, and/or nouns. In Leo Wetzels (ed.), The linguistics of endangered languages. Contributions to morphology and morphosyntax, 95-133. Utrecht: LOT Publications.

Miranda, Maxwell Gomes. 2014. Morfologia e morfossintaxe da língua Krahô (família Jê, tronco Macro-Jê). [Morphology and morphosyntax of the Krahô language (Jê language family, MacroJê stock)]. Brasilia: Universidade de Brasília dissertation.

Mithun, Marianne. 1997. Lexical affixes and morphological typology. In Joan Bybee, John Haiman \& Sandra A. Thompson (eds.), Essays on language function and language type dedicated to T. Givón, 357-371. Amsterdam \& Philadelphia: John Benjamins.

Mithun, Marianne. 1998. The sequencing of grammaticalization effects: A twist from North America. In Monika S. Schmid, Jennifer R. Austin \& Dieter Stein (eds.), Historical linguistics, 291-314. Amsterdam \& Philadelphia: John Benjamins.

Morse, Nancy L. \& Michael B. Maxwell. 1999. Gramática del Cubeo. [A grammar of Cubeo]. Bogotá: Editorial Alberto Lleras Camargo.

Mortensen, Charles Arthur. 1999. A reference grammar of Northern Embera languages. (Studies in the Languages of Colombia 7). Dallas, TX: SIL International \& University of Texas at Arlington.

Nikolaeva, Irina \& Andrew Spencer. 2019. Mixed categories: The morphosyntax of noun modification. Cambridge: Cambridge University Press.

Nonato, Rafael Bezerra. 2008. Ainore Boe egore: um estudo descritivo da língua Bororo. [Ainore Boe egore: A descriptive study of the Bororo language]. Campinas: Universidade Estadual de Campinas MA thesis.

O'Brien, Colleen Alena. 2018. A grammatical description of Kamsá: A language isolate of Colombia. Honolulu: University of Hawai'i at Mānoa dissertation.

Olawsky, Knut. 2006. A grammar of Urarina. (Mouton Grammar Library 37). Berlin \& New York: Mouton de Gruyter.

Oliveira, Christiane C. 2003. Lexical categories and the status of descriptives in Apinajé. International Journal of American Linguistics 69(3). 243-274.

Oliveira, Christiane C. 2005. The language of the Apinajé people of central Brazil. Eugene, OR: University of Oregon dissertation.

Overall, Simon. 2012. Attributive adjectives and the internal syntax of the NP in Aguaruna and other Jivaroan languages. Paper presented at Amazonicas-IV, Lima, Peru, 25 April. 
Overall, Simon. 2017. A grammar of Aguaruna (liniá Chicham). (Mouton Grammar Library 68). Berlin \& New York: Mouton De Gruyter.

Payne, Doris. 1987. Noun classification in the western Amazon. Language Sciences 9. 21-44.

Payne, Doris. 1990. Morphological characteristics of lowland South American languages. In Doris Payne (ed.), Amazonian linguistics: Studies in lowland South American languages, 213-241. Austin, TX: University of Texas Press.

Payne, Doris. 1994. The Tupi-Guarani inverse. In Barbara Fox \& Paul Hopper (eds.), Voice: Form and function, 313-340. Amsterdam \& Philadelphia: John Benjamins.

Payne, Doris L. \& Thomas E. Payne. 1990. Yagua. In Desmond C. Derbyshire \& Geoffrey K. Pullum (eds.), Handbook of Amazonian languages, 249-474. Berlin \& New York: Mouton de Gruyter.

Perri Ferreira, Helder. 2017. Yanomama clause structure. Nijmegen: Radboud Universiteit Nijmegen dissertation.

Pessoa, Katia Nepomuceno. 2012. Análise fonética e fonológica da língua Krenak e abordagem preliminar de contos Botocudo. [Phonetic and phonological analysis of the Krenak language and a preliminary approach to Botocudo short stories]. Campinas: Universidade Estadual de Campinas dissertation.

Pet, Willem J. A. 2011. A grammar sketch and lexicon of Arawak (Lokono Dian). (SIL e-Books, 30). SIL International.

Popjes, Jack \& Josephine Popjes. 1986. Canela-Krahô. In Desmond C. Derbyshire \& Geoffrey K. Pullum (eds.), Handbook of Amazonian languages, 128-199. Berlin \& New York: Mouton de Gruyter.

Queixalós, Francesc. 2006. The primacy and fate of predicativity in Tupi-Guarani. In Ximena Lois \& Valentina Vapnarsky (eds.), Lexical categories and root classes in Amerindian languages, 249-287. Peter Lang: Bern.

Quesada, Juan Diego. 2000. A grammar of Teribe. Munich: Lincom.

Radford, Andrew. 1981. Transformational syntax: A student's guide to Chomsky's extended standard theory. Cambridge: Cambridge University Press.

Reinöhl, Uta. 2020. What are and what aren't complex nominal expressions in flexible word order languages? Language Typology and Universals 73. 57-79.

Ribeiro, Eduardo Rivail. 2012. A grammar of Karajá. Chicago, IL: University of Chicago dissertation. Rießler, Michael. 2016. Adjective attribution. (Studies in Linguistic Diversity 2). Berlin: Language Science Press.

Rijkhoff, Jan. 2002. The noun phrase. Oxford: Oxford University Press.

Rodrigues, Aryon D. 1999. Macro-Jê. In R. M. W. Dixon \& Alexandra Aikhenvald (eds.), The Amazonian languages, 165-206. Cambridge: Cambridge University Press.

Rojas Berscia, Luis Miguel. 2013. La sintaxis y semántica de las construcciones causativas en el chayahuita de Balsapuerto. [The syntax and semantics of causative constructions in the Balsapuerto chayahuita]. Lima: Pontificia Universidad Católica del Perú MA thesis.

Romero-Figeroa, Andrés. 1997. A reference grammar of Warao. (LINCOM Studies in Native American Linguistics 6). Munich: Lincom.

Rose, Françoise. 2011. Grammaire de l'émérillon Teko: Une langue Tupi-Guarani de Guyane française. [A grammar of the Emerillon Teko: A Tupi-Guarani language from French Guiana]. (Langues et Sociétés d'Amérique Traditionnelle 10). Louvain: Peeters.

Rose, Françoise. 2014. Mojeño Trinitario. In Muysken Pieter \& Crevels Mily (eds.), Oriente, 59-97. La Paz: Plural Editores.

Rose, Françoise. 2018. The rise and fall of Mojeño diminutives through the centuries. Studies in Language 42(1). 146-181. 
Rose, Françoise. forthc. Word classes in Maweti-Guaraní languages. In van Lier Eva (ed.), The Oxford handbook of word classes. Oxford: Oxford University Press.

Rose, Françoise. in prep. A grammar of Mojeño Trinitario. Ms.

Ross, Malcolm. 1998. Possessive-like adjective constructions in the Oceanic languages of Northwest Melanesia. Oceanic Linguistics 37(2). 234-276.

Rosés Labrada, Jorge E. 2015. The Mako language: Vitality, grammar and classification. London, ON: University of Western Ontario dissertation.

Rose, Françoise \& An Van Linden. forthc. The derivational use of classifiers in Western Amazonia. In Steve Pepper, Francesca Masini \& Simone Mattiola (eds.), Binominal lexemes in crosslinguistic perspective: Towards a typology of complex lexemes (Empirical Approaches to Language Typology). Berlin \& Boston: De Gruyter Mouton.

Ruhlen, Merritt. 1991[1987]. A guide to the world's languages, vol. 1: Classification, 2nd edn. Stanford, CA: Stanford University Press.

Sakel, Jeanette. 2004. A grammar of Mosetén. (Mouton Grammar Library 33). Berlin \& New York: Mouton de Gruyter.

Seifart, Frank. 2005. The structure and use of shape-based noun classes in Miraña (north west Amazon) (MPI series in Psycholinguistics 32). Nijmegen: Radboud Universiteit Nijmegen dissertation.

Seifart, Frank \& Doris Payne. 2007. Nominal classification in the North West Amazon: Issues in areal diffusion and typological characteristics. International Journal of American Linguistics 73. 281-287.

Silva, Leia de Jesus. 2011. Morphosyntaxe du Rikbaktsa. [Morphosyntax of Rikbaktsa]. Paris Université de Paris 7-Dénis Diderot dissertation.

Silva, Wilson de Lima. 2012. A descriptive grammar of Desano. Salt Lake City, UT: University of Utah dissertation.

Smeets, Ineke. 2008. A grammar of Mapuche. (Mouton Grammar Library 41). Berlin \& New York: Mouton de Gruyter.

Sousa Filho, Sinval Martins de. 2007. Aspectos morfossintáticos dal Língua Akwẽ-Xerente (Jê) [Morphosyntactic aspects of the Akwẽ-Xerente language (Jê)]. Goiânia: Universidade Federal de Goiás dissertation.

Stenzel, Kristine. 2013. A reference Grammar of Kotiria (Wanano). Lincoln, NE: University of Nebraska Press.

Terraza, Jimena. 2009. Grammaire du Wichí: Phonologie et morphosyntaxe. [A grammar of Wichi: Phonology and morphosyntax]. Montréal: Université du Québec à Montréal dissertation.

Thiesen, Wesley \& David Weber. 2012. A grammar of Bora with special attention to Tone. (SIL International Publications in Linguistics 148). Dallas, TX: SIL International.

Valenzuela, Pilar M. 2003. Transitivity in Shipibo-Konibo grammar. Eugene, OR: University of Oregon dissertation.

Vallejos Yopán, Rosa. 2016. A grammar of Kukama-Kukamiria. (Brill's Studies in the Indigenous Languages of South America 13). Leiden: Brill.

Van linden, An \& Françoise Rose. 2017. How to distinguish between nouns and classifiers in binominal naming constructions? Answers from two Amazonian languages. In Paper presented at the 50th Annual Meeting of the Societas Linguistica Europae, Zürich, September 13.

Van de Velde, Freek. 2009a. De nominale constituent: structuur en geschiedenis [The nominal constituent: Structure and history]. Leuven: Leuven University Press.

Van de Velde, Freek. 2009b. The emergence of modification patterns in the Dutch noun phrase. Linguistics 47(4). 1021-1049. 
van der Voort, Hein. 2004. A Grammar of Kwaza. (Mouton Grammar Library 29). Berlin \& New York: Mouton de Gruyter.

van der Voort, Hein. 2005. Kwaza in a comparative perspective. International Journal of American Linguistics 71. 365-412.

van der Voort, Hein. 2006. Construções atributivas em Kwaza [Attributive constructions in Kwaza]. Boletim do Museu Paraense Emilio Goeldi 1(1). 87-104.

Vennemann, Theo. 1974. Theoretical word order studies: Results and problems. Papiere zur Linguistik 7. 5-25.

Vidal, Alejandra. 2001. Pilagá grammar (Guaykuruan family, Argentina). Eugene, OR: University of Oregon dissertation.

Vuillermet, Marine. 2012. A grammar of Ese Ejja, a Takanan language of the Bolivian Amazon. Lyon: Université Lumière Lyon 2 dissertation. 